\title{
Amerikan Hukukunda Evlat Edinmeye Bir Bakış: Vermont Eyaleti Örneği
}

\author{
A Perspective on Adoption in American Law: The Example of the \\ Vermont State
}

\section{Gözde Çağlayan Aygün * (iD}

\section{öz}

Evlat edinme kurumu eski hukuk sistemlerinden günümüze kadar değişik düzenlemelere uğrayarak gelmiştir. Elbette her ülke hukuku evlat edinmeyi kabul etmemiştir. Ancak kabul eden ülke hukukları bakımından da farklılıklar içermektedir. Bu farklılıklar ülke hukuklarının birbirinden farklı sistemlerle işlemesinin de bir sonucudur.

Anglo Sakson hukukunun etkisiyle ancak ondan farklı olarak Amerikan hukukunda da evlat edinme kurumu kabul edilmiştir; bu hususta pek çok düzenleme mevcuttur. Amerikan hukuk sisteminin Kita Avrupası hukuk sisteminden farklı olması, evlat edinme başvuru sürecinin, başvurunun değerlendirilmesinin ve evlat edinmeye karar verilmesinin daha esnek ve değişik olmasını da beraberinde getirmektedir.

Evlat edinmenin Amerikan hukukunda ortaya çıkış gerekçeleri tarihsel gelişmeleri ile önem taşımaktadır. Bugünkü düzenlemelere hangi süreçlerden geçilerek ulaşıldığı incelenmeye değer durumdadır.

Evlat edinme hem eyaletlerin yetkili kıldığı kamusal kurumlar hem de özel bazı kuruluşlar aracılığıyla gerçekleştirilmekte; hatta evlat edinme işlemine aracilık eden web siteleri bulunmaktadır. Bu husus evlat edinmenin hem ne kadar çok yönlü hem de ne kadar yaygın olduğunu gösterir niteliktedir.

Amerikan hukukunda federal devlet yapısı dolayısıyla hem federal bir düzenleme bulunmakta hem de eyaletlerin kendi kanunlarında da evlat edinmeye ilişkin düzenlemeler yer almaktadır. Eyalet hukukları farklılıklar gösterdiği için çalışmamızda federal düzenlemeyi benimseyen Vermont eyaletinin hukuki düzenlemesine yer vererek evlat edinme kurumunu inceleyeceğiz.

Anahtar Kelimeler: Evlat Edinme, Vermont Hukuku, Evlat Edinme Sistemleri, Abd Hukuku, Evlat Edinmenin Sonuçları

\section{ABSTRACT}

The adoption institution has come under various regulations from the old legal systems until today. Of course, not every country has agreed to adopt the law. However, it also contains differences in terms of the laws of the accepting countries. These differences are also a result of the country's laws functioning with different systems.

With the influence of Anglo Saxon law, but differently from it, the institution of adoption was also accepted in American law; There are many regulations in this regard. The fact that the American legal system is different from the Continental European legal system makes the adoption application process, the evaluation of the application and the decision for adoption more flexible and different.

The reasons for adoption in American law are important with their historical developments. It is worth examining through which processes the current regulations were reached.

Adoption is carried out through both public institutions authorized by the states and some private organizations; there are even websites that mediate the adoption process. This point shows how versatile and widespread adoption is.

Due to the federal state structure in American law, there is both a federal regulation and regulations regarding adoption in the laws of the states. Because state laws differ, we will examine the adoption agency by including the legal regulation of the state of Vermont, which adopts federal regulation.

Keywords: Adoption, Vermont Law, Adoption Systems, US Law, The Results of Adoptions

* Dr. Öğr. Üyesi, Anadolu Üniversitesi Hukuk Fakültesi Medeni Hukuk Anabilim Dalı

Sorumlu Yazar/Correspondence Author: Gözde Çağlayan Aygün

E-posta/E-mail: gozdecaglayanaygun@anadolu.edu.tr 


\section{GíRiş}

Amerika'da evlat edinmeyi düzenleyen modern anlamdaki ilk kanun 1851 tarihli Massachusetts Evlat Edinme Kanunu'dur. ${ }^{1}$ Bu Kanunla evlat edinme hâkim kararıla kurulan bir kurum olarak kabul edilmişti; hâkim evlat edinmeye karar vermeden önce evlat edinecek ailenin çocuğu büyütme kabiliyetine sahip olup olmadığını göz önünde bulundururdu. ${ }^{2}$ Bu tarihten sonra pek çok eyalette evlat edinme düzenleme altına alınmıştı; 1929 yılında ise tüm eyaletlerde kabul edilmiştir. ${ }^{3}$

Ancak Amerika federal bir devlet olduğu için eyaletler arasında hukuk uyumu yaratmak adına 1953 yılında federal düzeyde bir yasal düzenleme olan Uniform Adoption Act için çalışmalara başlanmış ve 1971 yılında bu çalışmalar tamamlanmıştır. ${ }^{4}$ Bu Act'in 1994 yılında American Bar Association (Amerikan Barolar Birliği) ve American Academy of Adoption Attorneys (Amerikan Evlat Edinme Akademisi Avukatları) tarafından üzerinde çalışılan bir versiyonu önerilmiştir. ${ }^{5}$

Önerilen bu versiyon sadece Vermont eyaletinde kabul edilmiştir. ${ }^{6}$ Uniform Adoption Act evlat edinmenin şartlarını, yargılama sürecini ve evlat edinmenin kişisel sonuçlarını içermekte; bu hususları detaylandırma, genişletme işini ise eyaletlerin kanunlarına bırakmaktadır. ${ }^{7}$ Dolayısıyla aslında Uniform Adoption Act bir model kanun niteliğindedir. Bu federal düzenleme dişında yine federal düzeyde olan bazı kanunlar da bulunmaktadır. Bunlara Indian Child Welfare Act of 1978, Adoption Assistance and Child Welfare Act of 1980, Intercountry Adoption Act of 2000 ile the Child Citizenship Act of 2000 kanunları örnek gösterilebilir. Yine özellikle miras hukukuna ilişkin olarak

1 RAPKE, D.R. (1999). A Critical History OfAmerican Adoption Law. 102 W. Va. L. S. 459-461; C.R.Mabry ve L.Kelly (2006). Adoption Law: Theory, Policy, and Practice, Buffalo. NY, s. 3; L. Kuntz (2013). Das geseztliche Erbrecht des Adoptivkindes in den USA. München: Carl Heymanns Verlag, s. 45; R.A.W.Howe (1983). Adoption Practice, Issues, and Laws, $1958-1983$. Family Law Quarterly Vol. 17, No. 2, s. 173-197, American Bar Association, s. 175.

2 Bu Kanunla aslında çocuğun yararı ilkesi kabul edilmişti. Çocuğun eğitim, bakım ve büyümesi için bu evlat edinme faydalı olacaksa hâkim ancak o zaman evlat edinmeye izin vermekteydi. Bu husus Kanunun ana metninde İngilizce haliyle şu şekildedir: "If, upon such petition, so prented and consented to as aforesaid, the judge of probate shall be satisfied of the identity and relations of the persons, and that the petitioner, or, in case of husband and wife, the petitioners, are of sufficent abiltiy to bring up the child, and furnish suitable nurture and education, having reference to the degree and condition of its parents, and that it is fit and proper that such adoption should take effect, he shall make a decree setting forth the said facts, and ordering that, from and after the date of the decree, such child should be demeed and taken, to all legal intents and purposes, the Child Of The Petitioner Or Petitioners".

3 H.D.Krause, L.D.Elrod, M.Garrison ve J.T.Oldham (2003). Family Law. Cases, Comments, and Questions. Minnesota, s. 316 (Kis. Krause); Kuntz, 2013, a.g.k., 46.

4 Kuntz, 2013, a.g.k., 49. Bu Uniform Adoption Act kısmen de olsa 6 eyalette kabul edilmişti. Bu eyaletler ise, Alabama, Arkansas, Montana, North Dakota, Ohio ve Oklohoma idi.

5 Kuntz, 2013, a.g.k., 50-51. Ayrıca bkz. https://www.loc.gov/law/help/adoption-law/unitedstates.php (Erişim tarihi: 27.02.2019).

6 Kuntz, 2013, a.g.k., 51. Vermont eyaleti bu düzenlemeyi aynen kabul etmiş ve ekstra bir iki düzenleme ekleyerek evlat edinmede bu düzenlemeyi esas almıştır. Eyaletin bu düzenlemesi için bkz. https://legislature.vermont.gov/statutes/ title/15A (Erişim tarihi: 27.02.2019).

7 Her eyaletin kendine özgü evlat edinme kuralları bulunmaktadır. Bu eyaletler ve kurallar için bkz. https://www.law. cornell.edu/wex/table_adoption (Erişim tarihi: 27.02.2019). 
evlatlığın haklarını ilgilendiren model kanun niteliğinde olan Uniform Probate Code da önemli federal düzenlemelerden biridir. ${ }^{8}$

\section{EVLAT EDINMENIN TARIHSEL GELIŞIMINE BIR BAKIŞ}

Evlat edinme gerçeği Amerikan toplumunun her alanında görülen mevcut bir sosyal olgudur ve biyolojik ve evlat edinme yolu ile oluşan ve gözle görülmeyen, düşündüğümüzden daha fazla kişiyi ilgilendiren bir konudur.

Amerikan tarihi boyunca, evlat edinme alt bir aile ilişkisi olarak görülmüşve ulusun biyolojik akrabalık ilişki anlayışının bağlayıcılığıyla, 17. ve 18. Yüzyıldaki ilkel yasal ve çevresel etkilerin sonuçları, 19. Yüzyıldaki hastalıklar, iç savaş, endüstrileşme, şehirleşme ve göçlerce, 20. Yüzyıldaki büyük buhran ve 2. Dünya savaşı ve cinsellik anlayışındaki değişimlerce şekillendirilmiştir. Amerikan tarihindeki bu yükselişler çocuk merkezci devlet anlayışını ve evlat edinmeyi düzenleyen federal yasaları doğurmuş, evlat edinme uygulamalarının profesyonelleşmesine ve standartlaşmasına sebep olmuş, çok katı örtüşme kriterinden uzaklaşılmasına, "evlat edinilebilir” çocuklar tanımının genişlemesine ve evlat edinme kayıtlarının sıkı saklanmasına karşı protestoların doğması sonucunu doğurmuştur.

Sömürge döneminde Birleşik devletler kültürünü ve hukukunu İngiltere'den almış olsa da evlat edinme noktasında İngiliz uygulamalarını terk etmişlerdir. İngiliz müşterek hukuk yasaları evlat edinmeyi tanımamaktaydı. Evlat edinmeye İngilizlerin yasal olarak karşı olması, miras kalması, gayri meşruluğa karşı olumsuz ahlaki bakış ve gönüllü nakil ve çırak verme gibi evlat edinmeye eşdeğer diğer bazı konuların dikkate alınması ve kan bağı akrabalarının mülkiyet haklarını koruma arzusundan kaynaklıydı. Bunun sonucu olarak İngiltere 1926 yılına kadar evlat edinme yasası çıkarmadı. ${ }^{9}$ Tam tersi Amerikan tarihindeki evlat edinme konusuna yönelik burada vurgulanması gereken nokta şudur; başlangıçta sömürgeci güçler biyolojik akrabalığın önceliği ile pek meşgul olmamakta, sınırlı ölçüde evlat edinme uygulaması ve daha sonra koruyucu aile olarak adlandırılacak olan çocuğun çırak verilmesi uygulamasına yöneleceklerdir. Sömürge döneminde Birleşik Devletler 'de bu soydaş ve soydaş olmayan aileler arasındaki geçişken sınır bazı durumlarda çocukların resmi olmayan kanallar ile evlat edinilmesini doğurmuş, özellikle tutucu Massachusetts ve Alman kökenli New York'ta durum bu yönde gelişmiştir. ${ }^{10}$

19. yüzyılın ortasında, resmi kanallar ile evlat edinme sayısı artmıştır ama tabi ki bu artışın ne kadar olduğunu tam olarak bilmek mümkün olmamıştır. Bu evlat edinmelerin birçoğu çocukları için isim değişikliği talebinde bulunan ailelerin isteği üzerine parlamentodan geçen özel kanunlar yolu ile

8 Kuntz, 2013, a.g.k., 51; A. Güvercin (2005). Yabancıların evlat edinmelerinin Uluslararası Hukuk açısından incelenmesi ve Türk Hukuku ile Amerikan Hukukunda evlat edinmeye ilişkin düzenlemeler. Yayınlanmamış Yüksek Lisans Tezi, Kocaeli: Kocaeli Üniversitesi, Sosyal Bilimler Enstitüsü, s. 83. G.P.Ahlers (2014). Adoptıon Law In The United States: A Pathfinder. Chıld And Famıly Law Journal, Vol:2:21, s. 21.

9 G.K. Behlmer (1998). Friends of the Family: The English Home and its Guardian. Chap. 6, Stanford University Press, Stanford; C.M.A. McCauliff (1986). The First English Adoption Law and Its American Precursors, Seton Hall Law Rewiew, 16:656-77.

10 J. Demos (1970). A Little Commonwealth: Family Life in Plymouth Colony. New York University Press, New York, s. 89. 
gerçekleşmiş. Massachusetts’te 1781 ile 1851 yılları arasında, eyalet meclisi 101 isim değişikliği vakası görülmüştür ki bu bir önceki yüzyıl için geçerli olan 4 rakamı ile karşılaştırıldığında dramatik bir artış anlamına gelmektedir. ${ }^{11}$

Resmi çocuk evlat ediniminin yasallaştırılmasına yönelik özel yasa çıkarımının artması Amerikan toplumunda, özellikle kuzeyde büyük sosyal değișikliklerin olduğunun bir yansımasıdır. 19. Yüzyılın ortalarına kadar, büyük çaplı göçler, şehirleşme ve fabrikalaşmanın ortaya çıkması ve maaşlı işçilik sömürge döneminde Birleşik Devletlerin kompakt, sabit, tarıma dayalı toplum yapısını, kalabalık, genişleyen kıyı şehirlerine dönüşmeye itmiştir. Bu zorlu ekonomik ve sosyal dönüşümlerin doğurduğu bir sonuç ise kırsal ve şehirsel fakirliğin bir problem haline dönüşmesi olmuştur. Bunun sonucunda, tüm Amerika'da ki insani ve dini çocuk korumasını önceleyen reformistler büyük ölçekli kurumlara dönüşmüşlerdir; yaşlılar evi ve özel yetimhaneler gibi.

Takip eden on yıllarda, çocuk yardımlaşma reformcuları ciddi şekilde yaşlı bakım evlerini ve yetimhaneleri pahalı olmalarından, katı disiplin, katı kurallar ve bağımsız ve çalışkan çocuk yetiştirmede başarısız olmalarından dolayı eleştirmiştir. John Locke ve Horace Bushnell gibi çocuk gelişimi teorisyenlerinin etkisiyle, bu reform hareketleri “Tanrının yetimhanesi” olarak adlandırdıkları aile kurumunu yüceltmişler ve ilgili kurumların suni ortamlarını eleştirmişlerdir ve aynı zamanda aileyi biraz pahalıda olsa, sosyal, bağımsız ve çalışkan çocuklar yetiştirme yeteneği olan kurumlar olarak adlandırmışlardır. ${ }^{12}$ Yeni eve yerleştirme hareketinde en etkili olan kurum ise 1853 yılında din adamı olan, New England tan taşınan ve Yale İlahiyat Fakültesi mezunu olan Charles Loring Brace tarafından kurulan New York's Children's Aid Society (CAS)'dir (New York Çocuklara Yardım örgütü).

Büyük oranda CAS taklit edilerek gerçekleştirilen bu büyük çaplı yerleştirme hareketi evlat edinme tarihinde önemli sonuçlar doğurmuştur. Amerika’nın evlat edinme yasasının kökeninin, ailelerine yeni bireyler eklemenin yasallaştırılmasını arzulayan orta sınıf çiftçilerin sayısında ki artışa dayandığı ifade edilebilir. ${ }^{13} 20$. Yüzyılın ortalarına kadar, eyalet parlamentoları, ilkel evlat edinme yasalarının ortaya çıkardığı yükü almak ve miras haklarını netleştirmek için ilk evlat edinme yasalarını parlamentodan geçirmeye başladılar. Bu genel evlat edinme yasaları, ki ilki 1846 yılında Mississippi'de ve 1850 yılında Texas'ta yasa olarak geçti (Her ikisi de geçmişlerinde İspanya ve Fransa yönetimine maruz kalmışlardır) Napolyon Kanununda düzenlenen sivil hukuk geleneklerinden etkilenmişlerdir. Ama her nasılsa, bu kanunlar “özel evlat edinme anlaşmalarını düzenlemek ve kaydını tutmak" için sadece basit bir hukuki prosedür geliştirmiştir, aynen bir tarla parçasının tapu kanalı ile kayda alınması örneğinde olduğu gibi. ${ }^{14}$

11 Evlat edinmenin özel bir sözleşmeden yasal bir kuruma nasıl gittiğine dair kısa bir açılama için bkz. E.A. Hoyt/M. Sherman (1996). Adoption and the Law in Vermont, 1804-1863: An Introductry Essay. Vermont History 64: 159173.

12 B. Wishy (1967). The Child and the Republic: The Dawn of Modern American Child Nurture. University of Pennslyvania Press, Philadelphia, cahps. 2-3.

13 S. B. Presser, The Historical Background of the American Law of Adoption, Journal of Family Law 11 (1971-72): 443-516.

14 M. Grossberg (1985). Governing the Hearth: Law and the Family in Nineteenth-Century America. University of North Carolina Press, s. 271. 
Tapu yolu ile evlat edinilmesine ilave olarak, eyalet parlamentoları ikinci tip bir genel evlat edinme yolunu yasalaştırmıştır. Kanun yapıcılar aile hukukunda meydana gelen büyük çaplı değişikliklerden etkilenmiştir, özellikle çocuk velayeti yasalarından. Devrim sonrası yargısal takdir hakkı ile birleştirilen ailelere karşı ortaya çıkan eşitlik düşüncesi Anglo-Amerikan yasalarca belirli bir temele oturtulmuş ataerkil velayet kurallarına zarar vermiştir, ki bu ataerkil kurallara göre hak kendisine verilmiş olan kişi yasal olarak kendisinde olan çocuk üzerinde neredeyse sınırsız hakka sahipti. Artan bir şekilde, ataerkil velayet yasalarının önceliği yargı tasarruflarınca sekteye uğratılmıs ve bayanlar ahlaki ve dini liderlik ve çocuk yetiştirmede özel bir kapasiteye sahip bireyler olarak görülmüştür. ${ }^{15} \mathrm{Bu}$ çocuk velayeti ve anne baba arasındaki hukuki eşitliğe yönelik çağdaş yasaların gelişmesinde iki en önemli elementlerden birinin ortaya çıkması ile sonlanmıştır. ${ }^{16}$ İkinci önemli dogmatik gelişme ise "çocuğun yüksek yararı" standartlarının 1840larda kanunlaşmasıdır, ki bu kanunları eyalet hakimleri velayet uyuşmazlıklarını çözmekte yaygın şekilde kullanmışlardır. Dört prensip bu çocuk koruma doktrini ile ilişkilendirilmektedir. İlki "çok küçük yaş" ya da "sağlıklı yaş" velayette dikkat edilmelidir. ${ }^{17}$ İkincisi ise daha büyük yaştaki oğlan çocukları ise babaların bakımına verilmelidir. ${ }^{18}$ Üçüncüsü ise mahkeme çocuğun oluşan duygusal bağlarına saygı duyup gözetmelidir. Dördüncüsü ise mahkeme eğer çocuk takdir kullanma yetisine sahipse, çocuğun arzularını dikkate alarak karar vermelidir. ${ }^{19}$

$\mathrm{Bu}$ yeni ortaya çıkan çocuk velayetine yönelik fikirler, 1851 yllında Massachusetts parlamentosunca "Çocuk evlat edinme yasası" adı altında yeni genel evlat edinme yasalarına monte edilmiştir. Evlat edinme tarihinde bir dönüm noktası rolü üstlenen bu yasa, çocuğun menfaatine ve hakimlere evlat edinecek aday ailenin çocuk için uygun olup olmadığının kararını vermesi inisiyatifi bırakarak Amerikảnın ebeveynlik ve çocukluk anlayışı noktasında edindiği yeni perspektifi yansıtmaktadır. Buna ek olarak, yasa evlat edinen anne babası ve çocuk arasında var olan yasal bağı güçlendirmiştir ve böylece çocuğu orijinal ailesine karşı olan yasal zorunluluklardan koparmıştır. ${ }^{20}$ Massachusetts Adoption Act (Massachusetts Evlat edinme Yasası), sıklıkla bu isimle çağrılmaktadır, Amerikan toplumu ve ailesi tarihinde bir set görevi görmüştür. Anne baba-çocuk ilişkilerini sadece kan bağı yönünden tanımlamanın yerine, bir biyolojik anne babanın duygusal ve sorumluluklarının varlığını kabul ederek yasal olarak bir aile oluşturmanın artık mümkün olduğunu ortaya koymuştur. ${ }^{21} 1853$ 'te benzer bir çocuk merkezli evlat edinme yasasını parlamentosundan geçiren Pennsylvania eyaleti mahkemeleri çocuğun olası bir evlat ediniminin çocuğun menfaatine olacağını temin etmesini zorunlu kılmıştır. ${ }^{22}$ Sonraki 25 yl boyunca, Massachusetts Adoption Act (Massachusetts Evlat Edinme Yasasi) bir model olarak düşünülmüş ve 24 eyalet benzer yasaları parlamentosundan geçirmiştir. ${ }^{23}$

15 Grossberg, s. 238.

16 J.S. Zainaldin (1979). The Emergence of a Modern American Family Law: Child Custody, Adoption, and the Courts, 17961851. Northwestern University Law Review 73, s. 1038.

17 Zainaldin, s. 1072.

18 Zainaldin, s. 1073.

19 Zainaldin, s. 1073-1074.

20 Zainaldin, s. 1074-1085.

21 Zainaldin, s. 1085.

22 Grossberg, s. 272.

23 H.L. Witmer (1963). Independent Adoptions: A Follow-up Study. Russell Sage Foundation, New York, s. 30-31. 
Victoria döneminde İngiltere’de evlat edinme uygulamalarında meydana gelen reformlar Amerika Birleşik Devletlerindeki evlat edinme reformlarıyla örtüşmektedir. CAS bu değişimlerde aracı bir rol üstlenmiştir, her ne kadar böyle bir niyeti olmasa da. Brace 'in bu katı çocuk yerleştirme sistemi (bunun en temel özelliği biyolojik ailelerin parçalanmasıdır) Amerika’nın yüksek bebek ölüm oranları ile birleşince (kalabalık şehirlerde hijyen yoksunu ortamlar ve tıbbi bilgi eksikliği) Progresive Era (1900-1917) olarak bilinen ve tutucu çocuk koruma kurumlarının büyümesini ve sosyal hizmetler çalışanlarının profesyonelleşmesini ve evlat edinme süreçlerinin standartlaşmasını sağlayan dönemin başlamasına yardımcı oldu ve evlat edinme süreçlerinin düzenlenmesinde eyaletlerin rollerini genişletti. ${ }^{24} \mathrm{Bu}$ hareketin amaçlarının hayata geçirilmesi, yani orijin aileleri birlikte tutmak, aile bağlarının kopmasında biyolojik ailenin rızasının alınmasının temin edilmesi, evlat edinme izni öncesi evlat edinecek ailelerin ve yuvanın iyice araştırılması ve üçüncü taraf ve bağımsız evlat edindirmelerin engellenmesi (doktor yada avukat yolu ile evlat edindirilmesi uygulaması) profesyonel sosyal hizmetler çalışanlarının varlık sebebi haline gelmiştir. ${ }^{25}$

Progressive Era (İlerlemeci Dönem) Katolik liderleri bağımlı çocuklar yaratma noktasında evlat edinmeyi kabullenmede yavaş davranmalarına rağmen, bu dönem evlat edinme tarihinde ikinci mihenk taşı rolü üstlenmiştir çünkü konu ilk defa popüler gündemin bir parçası haline gelmiştir. "Rescue a Child and Save the Nation: The Social Construction of Adoption in the Delineator, 19071911” (Bir çocuk kurtar ve Ulusu Koru: 1907-1911 dönemi evlat edinmenin Sosyal İnşası) isimli eserinde, Julie Berebitsky popüler bir kadın dergisi olan Delineator’nn nasıl başarılı bir çocuk koruma kampanyası yürüttüğünü ele almıştır ki bu o dönemde evlat edinmeyi popüler hale getirmiş ve üvey anneliğin tanımını genişletmiştir. ${ }^{26}$

20. yüzyılında başlarında, çocuk yardım reformistleri eyaletlerin yasama kurumları bünyesinde lobi faaliyetlerine başladılar. Evlat edinme yönünde, en önemli yasama sonuçlarından bir tanesi 1917 yılındaki Children's Code of Minnesota'dır, ki bu kurum sonraki 20 yıldan fazla bir dönemde eyalet yasaları için bir model olmuştur. Minnesota eyaleti önerilen evlat edinme adayı ailenin çocuk için uygun olup olmadığının araştırılmasını zorunlu kılan ilk eyalet olmuştur. Eyalet denetim kurulu evlat edinme dilekçelerini incelemekten sorumluydu ve tüm evlat edinme dosyalarına yönelik mahkemelere tavsiye yazmaktan sorumlu bir kuruldu. Yasa ayrıca çocuklar için evlat edinen ailenin evinde 6 aylık bir deneme amaçlı ikamet olanağı sağladı. Dahası, evlat edinme sürecinde doğrudan yer alanların, evlat edinilen kişiler, evlat edinen anne babalar ve biyolojik annelerin kayıtlara erişebilmesine rağmen, ilgili yasa evlat edinme dosyalarını kamunun erişimine kapattı. Bu nokta, Amerikan evlat edinme tarihi boyunca eyalet yasaları üçlü grup üyelerinin evlat edinme kayıtlarına erişimi engel olduğuna yönelik yaygın inanışa rağmen, önemlidir. ${ }^{27}$ Çocuk koruma reformcuları Minnesota’nın çocuk yasasını model bir yasa olarak adlandırmışlardır. ${ }^{28}$ Sonraki 20 yıl boyunca, evlat

24 E. Wayne Carp (2002). Adoption in America: A Historical Overview of American Adoption, University of Michigan Press, s. 7.

25 Carp, s. 7-8.

26 Carp, s. 7-8.

27 Carp, s. 7-8.

28 G-F.D. Ma (1948). One Hundred Years of Public Services for Children in Minnesota. University of Chicago Press, Chicago. 
edinme reformcuları çabalarını eyalet yasa yapıcıları üzerinde lobi faaliyetlerine yoğunlaştırdılar ve süreçte rol alan herkesin belirli koruma statüsüne sahip olmasını sağlamayı amaçlamışlardır; mesela rızaya karar verme, sosyal araştırma, deneme süresi ve kayıtların gizliliği gibi. ${ }^{29}$

Progressive Era dönemi sosyal hizmetler uzmanları hem üniversite hem de ulusal kurumlardaki reform çabalarını hem halka açık hem de özel olacak şekilde devam etmişlerdir. Birçok yükseköğretim kurumunda Yüksek Lisans enstitüleri kurulmuştur ve buna Chicago üniversitesi dahildir. Böylece sosyal hizmetler uzmanlarının profesyonelleşmesi hedeflenmiştir. ${ }^{30}$ Birleşik Devletler Çocuk Bürosu 1912 kuruldu ve toplumu evlat edinme noktasında bilgilendirmede öncü bir kurum haline geldi. 2 Dünya savaşı boyunca, evlat edinme ajanslarına yönelik standartların belirlenmesinde, eyalet yasa yapıcıları, sosyal hizmetler uzmanlarını, araştırmacıları yönlendirmede, aracı bir rol oynadı ve halkı evlat edinmeye yönelik her konuda bilgilendirdiler. 1921'de, kâr amacı gütmeyen özel bir kurum olan Child Welfare League of America (CWLA) (Amerikan Çocuk Koruma Ligi) kuruldu. Hem halk hem özel ajanslar için evlat edinmeye yönelik standartlarında belirlenmesinde artan bir öneme sahip oldu. $^{31}$

Evlat edinme uygulamalarının karşısında bir argüman olarak sunulan ise Amerikan kültüründe akrabalığın kana dayalı bir esasa göre tanımlanmış olması gelmektedir, bundan dolayı evlat edinme sosyal olarak kabul edilmeyen bir olgu olarak görülmüştür. Sosyal hizmet uzmanları olası bir çocuğun evlat olarak bir eve alınmasının anormal bir şey olmadığı noktasında ikna etmek için evlat edinmeye karşı var olan yaygın önyargılarla baş etmek zorunda kaldılar. 19. Yüzyılın sonlarında 20. Yüzyılına başlarında, Amerikan halkının büyük bir kısmı evlat edinmenin yapay ya da ikinci sınıf bir aile yaratan suni bir eylem olduğuna inanmaktaydı. Bu noktada kullanılan dil evlat edinmenin doğasına vurgu yaptı ve evlat edinen ailelerin her zaman doğal ve normal olduklarına vurgu yaptı. ${ }^{32}$ Ayrımcı yasalar evlat edinme ilişkisinin doğası gereği zararlı olduğu düşüncesine vurgu yapmıştır. Miras davalarında, mesela, jüriler sıklıkla evlat edinmenin kan bağı prensibini ihlal ettiğine yönelik kararlar almışlardır. Böylece, evlat edinilen çocuk biyolojik çocuklar kadar mirastan hak alma ayrıcalığına sahip değillerdi. Evlatlıkların konu olduğu vesayet ihtilafları içeren diğer davalarda hem mahkemeler hem parlamentolar biyolojik anne babanın çocuklarının koruma haklarını alma yönünde karar alma eğilimi göstermişlerdir. ${ }^{33}$

1929 yılında büyük ekonomik buhranın başlamasından hemen sonra, eşi benzeri görülmemiş bir işsizlik, evsizlik, açlık ve sefalet çocuklara uygulanan yasalar üzerinde ekstra bir etki yarattı çünkü yerel hükümetler ve özel ajanslar bu büyük işsizlik oranları ve yarattığı etki ile mücadele etmeye çalışıyorlardı. 1933 yılında Franklin Roosevelt tarafından yasa haline getirilen Federal Emergency Relief Act (Federal Acil Rahatlama Yasası) ve 1935 yılındaki the Social Security Act (Sosyal Güvenlik

29 E. W. Carp (1998). Family Matters: Secrecy and Disclosure in the History of Adoption. Harvard University Press, Cambridge (Family Matters), s. 21-25.

30 R. Muncy (1991). Creating a Female Dominion in American Reform, 1890-1935. chap. 2. Oxford University Press, New York.

31 Carp, Family Matters, s. 22-28.

32 R. L. Jenkins (1935). On Adopting a Baby: Rules for Prospective Adoptive Parents, Hygeia 13, s. 1068.

33 P. Romanofsky (1969). Early History of Adoption Practices, 1870-1930. University of Missouri at Columbia, s. 67-69. 
Yasası) çocuk koruması için çok ihtiyaç duyulan fonu sağladı. Bu federal yasalar ile ortaya çıkan etki mevcut evlat edindirme programlarını güçlendirdi ve yetkilerini genişletti ve aynı zamanda o ana kadar mevcut olmayan yeni eyalet koruma departmanlarının oluşumunu sağladı. 1937 yılının sonuna doğru, 44 eyalet ya yeni bir evlat edindirme yasası çıkardı ya da mevcut olanı revize etti ve bu çıkarılan yasaların birçoğu, çocuk aday ailelere mahkeme tarafında verilmeden önce eyalet koruma departmanlarının iyi bir araştırma yapmasını ya da lisanslı bir evlat edindirme ajansının aracı olmasını zorunlu kıldı.42

1930’lu yılların sonlarına doğru, CWLA, üye toplumların ticari evlat edindirme ajanslarının ve kadın sığınma evlerinin uygulamaları hakkında ilettikleri şikayetlerin sonucu olarak evlat edinme standartlarını incelemeye başladı. Bu tarz kötü üne sahip olan the Cradle Society, the Willows ve the Veil Maternity Home gibi kurumlar evlat edinen ailelerden ücret aldılar ve yaygın kabul gören sosyal hizmetler uygulamalarını ihmal ettiler ve evlat edindirme sürecine doğrudan müdahil olan taraflara yönelik yeterli güvenlik sağlayamadılar. CWLA’ye üye ajanslar doktorlar tarafından gerçekleştirilen bağımsız evlat edindirme uygulamalarına yönelik endişeleri vardı.43 1940'larda, the Children's Bureau (Çocuk Bürosu) Birleşik Devletlerdeki evlat edindirmelerin yarısından biraz fazlasının lisanslı ajansların alanı dışında gerçekleştiğini tahmin etmekteydi. Profesyonel sosyal hizmetler uzmanları uygun bir sosyal araştırmanın yapılmamasının sıklıkla trajedilere sebep olduğuna yönelik artan bir inanca sahipti.

Uygunsuz işleyen evlat edinme sosyal çalışma faaliyetlerine ve artan bağımsız evlat edindirmelere bir tepki olarak, 1938'deki CWLA tek bir sayfada özetlenebilecek olan kendi evlat edinme standartlarını belirledi. ${ }^{34} \mathrm{Bu}$ standartlar çocuklara yönelik güvenlik standartları, evlat edinen ailelere yönelik standartlar ve eyalete yönelik standartlar olmak üzere gruplandırıldı. Çocuklara yönelik koruma standartları aynı zamanda biyolojik anne babalara yönelik güvenlik standartları olarak isimlendirilebilir; yani bu standarda göre çocuk kan bağı olan kişilerden zorunlu olmadıkça ayrılmamalıdır. Profesyonel sosyal hizmetler uzmanları hala çocuğu mümkünse biyolojik ailesi ile birlikte bir arada tutmanın en arzulanan yöntem olduğunu ifade etmektedirler. İkinci ve üçüncü koruma standartları ise evlat edinen ailelere yönelik olan standartlardır, yani onların motivasyonlarının korunması ve evlat edinmeye yönelik uygunluklarının saptanmasına yöneliktir. Evlat edinen aileler tam olmayan ailelerinin çocuk evlat edinerek tam bir aile haline dönüşebileceğini, iyi bir aile ortamına ve yaşamına sahip olmayı ve birbirleriyle uyum temelinde evlat edinmeyi arzulanmaktadır. Ayrıca aday ailelerin birbirlerini sevmeye, destekleme ve evlat edinilen çocuğu eğitmeye yönelik arzuları olmalıdır. Evlat edinen aile iyi bir çocuk edindirme ajansından kendi bilgilerini biyolojik ailelerden gizli tutacaklarından, fiziksel ve zihinsel olarak evlat edinilen çocuğun evlat edinen ailenin beklentilerini karşılamasını ve evlat edinme sürecini gereksiz ifşalardan kaçınarak yürütmesini beklemektedir. Son olarak, eyalet kendi menfaatine ve çocuğun çıkarına evlat edinmenin sonlanmasından önce bir deneme süresi uygulamalı ve evlat edinilen çocuğun doğum kayıtlarını olası gayrimeşruluğun utanç konusu olmaması için uygun şekilde değiştirmelidir. İlgili standartlar en iyi sonuç için hem biyolojik

34 Detaylı bilgi için bkz. https://pages.uoregon.edu/adoption/people/cwla.html 
hem de evlat edinen aileler iyi bir çocuk edindirme kurumundan danışmanlık hizmeti almalıdırlar. ${ }^{35}$ CWLA çocuk edindirme kurumlarına yönelik model evlat edinme standartları sunmuştur. CWLA standartlarına uymamak ilgili ligden çıkarılmayla sonuçlanmıştır. ${ }^{36}$

2. Dünya savaşı öncesi on yılda, hem çocuk bürosunun evlat edinmeye yönelik artan ilgisi ve CWLA'nın evlat edinme standartları, gelecekteki olası evlat edindirme reformlarının ve uygulamalarının başladığına dair bir işaretti. Eski düzenin değiştiğine dair ilk işaret evlat edinilen çocuğun çevresindeki öjenik yaftalamanın 1920 ve 1930’larda azalmaya başlamasıdır. Çünkü yapılan araştırmalar evlat edinmenin başarılı sosyal uyumunu ortaya koydukça, tıbbi uzmanlar öjenik alanını bir bilim olarak tanımışlar ve evlat edinme ajansları ve popüler medya evlat edinen anne babaları evlat edinmenin olası tehlikelerinin elde edilen bilimsel gelişmeler sayesinde büyük oranda giderildiği noktasında teminat vermişlerdir. Evlat edinme uygulamalarının değiştiğine yönelik ikinci işaret ise sosyal uzmanların ve eyalet bürokratlarının git gide evlat edinmeyi gizlemeye yönelik artan eğilimleridir. Bunun birçok sebebi vardır; evlat edinme sürecini savunmaya yönelik arzu, çalışanların güç ve etkilerinin artırılması ve müşterileri psikoanalitik teoriye göre davranarak sosyal hizmetler uzmanlarının profesyonelleşmelerine destek olmak. Bunun sonucunda, evlat edinmede gizlilik 2. Dünya savaşı sonrası yaygınlık kazandı ve doğrudan evlat edinmenin taraflarının özel hayatlarına erişim noktasında sınırlamalar getirmiştir. ${ }^{37}$

1940’tan sonra, demografik değişiklikler, evlat edinilebilir çocukların sayısında artış gibi, evlat edinme uygulamalarında değişimlere hız vermiştir. Ölüm, boşanma ve terk etmelerden kaynaklı parçalanan yuvaların sayısında devam eden artışa ilaveten, nikâh dışı doğan çocukların sayısı dramatik bir şekilde artış yaşanmıştır. Savaş zamanı sosyal bağlarda yaşanan gevşemelerle birlikte, gayrimeşruluk oranında artış yaşanmıştır, özellikle beyaz ırk dışındakiler arasında ve bu sonraki kırk yll boyunca durum böyle devam etmiştir. ${ }^{38}$

Soğuk savaş boyunca çocuksuz ailelerin bebeğe yönelik talepleri geleneksel evlat edinme uygulamalarında yaşanan radikal değişimlere götüren ilave bir faktör olmuştur. 1940larda başlayarak ve 1950lerde zirveye ulaşarak, evliliklerde ve doğum oranlarında yaşanan baby boom era (bebek patlaması) döneminin yükselmesi, evlat edinmeye yönelik çocuğa olan talepte artıştan sebep oldu ve bu durum evlat edindirme ajanslarına yönelik çocuk için inanılmaz bir talep artışılla sonuçlandı. Ebeveynlik vatanseverliğin bir gerekliliği haline geldi. Medya bebekleri romantikleştirdi, anneliği yüceltti ve babalığı erkeklikle ve iyi vatandaşlıkla özdeşleştirdi. Tarihçi Elaine Tyler May’e göre, bu durum çocuksuz aile olmayı eşi görülmemiş bir şekilde marjinalleştirdi. Çocuksuz olmanın ve toplum baskısının yarattığı huzursuzlukla, kısırlıklarının kendilerine yüklediği "utanç" tan kurtulmak için inanılmaz sayıda çift evlat edinmenin yollarını aramaya başladılar. ${ }^{39}$ Evlat edinme ajansları büyük bir çocuk talebiyle karşılaştılar. Evlat edinme başvurusunda bulunan sayısı inanılmaz çocuksuz çiftlere

35 "Minimum Safeguards in Adoption," Nov. 5, 1938, CWLA Records, box 15, folder 5.

36 Z. R.Turitz,(1967). Development and Use of National Standards for Child Welfare Services,"Child Welfare 46, s. 246-48

37 Carp, Family Matters, chap. 4.

38 Carp, s. 12.

39 E. T. May (1995). Barren in the Promised Land: Childless Americans and the Pursuit of Happiness. Basic Books, New York, s. 127 ve s. 156 
katkı sunmak için yeni tıbbi tedavi araçları kullanıma sokuldu; meni incelemesi, tüp açıklığı testi ve endometriyal biyopsi, ki bu yöntemler doktorların üreme için evliliğin daha başlarında çiftlerin fiziki sağlıklarına yönelik teşhis koymalarını olanaklı kılmıştır. Böylece, evlat edinme çocuksuz kısır çiftler için şaşırtıcı bir hizmet haline geldi. ${ }^{40}$

Bu faktörler, savaş zamanı koşullarıyla birleşince, evlat edinme başvurularında önemli bir artışa sebep oldu. 1937 ile 1945 yılları arasında, evlat edinme oranı üç kat artış kaydetti, 16.000'den 50.000 gibi bir yıllık rakama ulaştı. On yıl sonra, evlat edinmelerin sayısı neredeyse iki misline çıkmıştı, 93.000 gibi ve 1965'e kadar, 142.000 rakamına ulaştı, bu rakamın 1/3' ile yarısına kadarı akrabalara evlatlık verilme şeklindeydi. ${ }^{41} 30$ yıldan daha az bir zaman diliminde, evlat edinmelerin sayısı neredeyse 9 kat artış kaydetti. Alınan başvuruların sayısından şakına dönen ve katı kurallardan bunalan evlat edindirme ajansları çocuksuz çiftler arasında husumet ve dargınlıklar doğurdu. ${ }^{42}$

2. Dünya savaşının sonlanmasıyla, ilk defa ülkeler arası evlat edinme süreci başlamış oldu. ${ }^{43} 1946$ ve 1953 yılları arasında, Amerikan vatandaşları ve örgütleri, International Social Services, American Branch gibi, Birleşik devletlere evlat edindirmek üzere 5814 yurt dişı doğumlu ve terkedilmiş çocuk getirdi ve bunların birçoğu savaşın gerçekleştiği alanlar olan Yunanistan, Almanya ve Japonya'dandı. Araştırmacılar Howard Altstein ve Rita J. Simon’n ülkeler arası evlat edinme sürecinin ikinci aşaması diye adlandırdığı aşama 1953 Kore savaşının sonlanması ile 1962 yılı arasıdır. Bu dönemde, “tarihte ilk defa, büyük sayıda batılı çift, çoğunluğu Amerika'da, kendilerinden ırk ve kültür olarak farklı çocukları evlat ediniyorlardı”. Bu dönemde evlat edinilen 15.000 çocuğun üçte biri Asya (Kore Cumhuriyeti) kökenliydi ve 32.000 yabancı ülke doğumlu olan ve 1966 ile 1976 yılları arasında Amerikalılarca evlat edinilen çocukların \%65’i yine benzer şekilde Kore Cumhuriyeti kökenliydi. Bunun sonucu, Koreli çocuklar Birleşik Devletlerde en büyük oranda evlat edinilmiş çocuk grubu oldu ve ülke dünyanın önde gelen evlatlık yabancı çocuk alıcısı haline geldi. ${ }^{44}$

1970’lerden 1990'lara, Amerikan toplumundaki öngörülemeyen ırksal, cinsel, anayasal ve demografik değişiklikler evlat edinme tarihindeki dördüncü eşiği daha derinleştirerek beşinci eşiği başlattı, ki bu eşik açık evlat edinme ve evlat edinme hakları hareketi ile öne çıkmıştır. Yeni enerji ile yola devam eden bu trend özel ilgiye muhtaç çocukların evlat edindirilmesine odaklandı, özellikle Afroamerikan kökenlilerin. 1967'de, CWLA Adoption Resource Exchange of North America (Kuzey Amerika Evlat Edinme Kaynak Değişimi) isimli evlat edindirilmesi zor çocuklar için bağımsız bir ulusal takas odası kurdu ve bu oda yılda fiziksel, duygusal ve zihinsel olarak özürlü iki yüz çocuğa yuva buldu. ${ }^{45} 1969$ yılına kadar, kamu ve özel evlat edindirme ajanslarının azınlık çocukları için yuva bulmaya yönelik çabalarının birleşmesi 19.000'den fazla çocuğun yuva bulması ile sonuçlandı. Bu yıl evlat edinilen 171.000 çocuktan, 14.000’i (Yüzde 8) Afroamerika kökenliydi. ${ }^{46}$ Bu bahsi geçen

40 R. Frank (1956). What the Adoption Worker Should Know about Infertility, Child Welfare 35, s. 1-5.

41 Carp, s. 13.

42 Carp, Family Matters, s. 29-31.

43 Carp, s. 14-15.

44 H.Altstein/R.J. Simon (1990). introduction to Intercountry Adoption: A Multinational Perspective, New York, s. 3.

45 CWLA,Adoption Resource Exchange of North America(New York:CWLA,1968).

46 U.S. Department of Health, Education, and Welfare, National Center for Social Statistics, Adoptions in 1969, supp.to 
programlara rağmen, hala yerleştirilmeyi bekleyen on binlerce yaşlı, azınlıklara ait ve fiziksel ve zihinsel yönden özürlü çocuk bırakmıştır.

Sosyal hizmetler uzmanları özel-ilgiye muhtaç evlat edindirmelerin sayısının artırılması için birçok farklı yönteme başvurmuştur. ${ }^{47}$ Ajansların yoğun çabalarıyla, beyaz ailelerin siyah çocuk evlat edinmeyi tercih etmeye başladığı görülmüştür veya kendilerine uzmanlarca bir siyah çocuk önerildiğinde kabul ettikleri görülmüsstür. 1965 yllına kadar, ırklar arası evlat edinme küçük bir devrim niteliğindeydi çünkü ülkedeki neredeyse tüm ajanslar beyaz ailelere siyah çocuk evlatlık vermekteydi. ${ }^{48}$ Dört sene sonra, CWLA yeni uygulamayı daha iyi yansıtmak için standartlarını revize etti, ırksal geçmişin evlat edinmede belirleyici olamayacağını ifadeye ekledi ve ajanslara farklı ırklardan çocuk evlat edinmeyi isteyen ailelerin isteklerini karşılama noktasında hazır olmaları tavsiyesinde bulundu. ${ }^{49}$

Profesyonel sosyal hizmetler uzmanları baş döndürücü bir esneklik ile evlat edinmenin tanımını liberalleştirmiş, 19601 yılların şaşalı olayları bu tarz çabaların önüne geçmiştir. İşin esasında, sosyal hizmetler uzmanları 1960lı yılların radikalizminin en sonunda evlat edinme uygulamalarını ve politikalarını etkileyeceğini tahmin edemediler. Resmi makamlar ve sosyal hizmetler görevlileri hem meslek içi hem meslek dışından olan kilise muhalifleri 1970lerde inançlara meydan okudukları zaman büyük bir sürprizle karşılaştılar. İlk memnuniyetsizlik manifestosu 1972 yllında siyah güç hareketinden ve onun rrk ayrımcllı̆g üzerindeki etkisinden etkilenen siyah sosyal hizmetler uzmanları ırklar arası evlat edinmeyi bir tür kültürel soykırım olarak adlandırdılar. ${ }^{50}$ National Association of Black Social Workers (Siyah Sosyal Hizmetler Çalışanları Ulusal Örgütü)nün ırklar arası evlat edinmeye karşı mücadelesi dikkat çekiciydi. 1972'de ırklar arası evlat edinme yüzde 39 düştü ve 1569 olarak gerçekleşti ve üç sene sonra, sadece 831 rrklar arası evlat edinme gerçekleşti. ${ }^{51}$

Sosyal hizmetler uzmanları ayrıca sağlıklı beyaz çocukların evlat edinmeye yönelik elde edilebilirliğindeki radikal düşüşü öngörmekte başarısız oldular, ki bu durum evlat edinme politikalarında çok önemli değişimlerin ortaya çıkmasına sebep oldu. Bunun birçok sebebi vardır; 1960lı yıllardaki cinsel devrim, doğum kontrol olanakları, Yargıtay'in Roe v. Wade'de (1973) evlat edinmeyi yasallaştırması ve evli olmayan annelerin bebeklerinin evlat edinilmesine yönelik haklarından vazgeçmede gösterdikleri isteksizlik. Amerikan toplumundaki bu kültürel, sosyal, legal ve demografik değişikliklerin sonucu, evlat edinmenin sayısı önemli oranda düştü. Amerika’da akraba olmayanlar arası evlat edinme 1970'te 89.200 gibi rekor sayıdan 1975 yılında 47700'e düşmüştür. Bu sayı 1982 yllında biraz yükselmiş ve 50720'ye yükselmiştir ve sonraki on yıl boyunca bu değerlerde kalmışır..$^{52} 1975$ yılına kadar, bazı ajanslar sağlıklı beyaz çocuğa yönelik evlat edinme taleplerini geri

Child Welfare Statistics-1969 (Washington,D.C.: U.S. Government Printing Office, 1969).

47 H. Fradkin (1958). Adoptive Parents for Children with Special Needs. Child Welfare 37, s. 1-6.

48 B. Q. Madison/M. Schapiro (1973). Black Adoption-Issues and Policies: Review of the Literature. Social Service Review 47, s. 531-60.

49 CWLA, Standards for Adoption Service, rev. ed. (New York: CWLA, 1968), 34.

50 A.J.Matusow (1984). The Unraveling ofAmerica: A History of Liberalism in the 1960s. Harper and Row, New York.

51 H. Altstein/R. J. Simon (1977). Transracial Adoption:An Examination of an American Phenomenon. Journal of Social Welfare 4, s. 65.

52 National Committee for Adoption, Adoption Factbook (Washington, D.C.: National Committee for Adoption, 1985), 14. 
çevirdiler. Sosyal hizmetler uzmanları sıklıkla aday ailelere bu tarz bir çocuk için 3 ile 5 yıl arasında beklemek zorunda kalacakları yönünde bilgilendirme yaptı. ${ }^{53}$

1970’lerin doğurduğu ikinci bir sonuç ise evlat edinilebilir çocuk nüfusu tanımının yenilenmesiydi ve böylece daha kapsayıcı ama çocuğun fiziki, zihinsel, ırksal ve dini özelliklerinin aday aile ile eşleşmesi noktasına daha az önem verir bir hal aldı. Evlat edinilebilir nüfus artan bir şekilde yaşı ileri çocuklardan, azınlık grupların çocuklarından ve özel ilgiye muhtaç çocuklardan oluşmaktaydı. 1990’larda, uyuşturucuya maruz kalmış bebekler, AIDS’li çocuklar ve HIV pozitif doğan çocuklar bu bahsi geçen özel ilgiye muhtaç kategorisine eklenmiştir. Evlat edinecek bir aile bulamayan ya da evlat edinilmeden yasal olarak muaf olan bu çocukların yaklaşık yüz bini koruyucu aile sisteminde sabit olarak kaldı ve koruyucu aileler arasında dolaştırıldı. Bu durum kongrenin 1980 yılında the Adoption Assistance and Child Welfare Act (Evlat edindirme Yardımı ve Çocuk Koruma Yasası) yasasını geçirmesine sebep oldu ki bu yasa çocuk evlat edinme işine yönelik çıkan ilk federal yasadır. Kongrenin bu yasası çocuk koruma ajanslarının yerleştirme öncesi engelleyici hizmetler sunmalarını, çocukların biyolojik aileleriyle tekrar birleşmelerini sağlayıcı adımlar atmalarını ve uzun dönemli koruyucu ailelerde bırakılan çocukların durumlarının periyodik olarak değerlendirilmesini zorunlu kıldı. Kalıcılığın planlanması yasası ki daha sonra bu isimle adlandırılacaktır, çocukları sabit evlere yerleştirmenin yollarını aramıştır, bunu ya çocukları orijinal ailelerine göndererek veya evlat edinen ailelere göndererek yapmışlardır. Adoption Assistance and Child Welfare Act (Evlat Edinme Yardımı ve Çocuk Koruma Yasası) yasası ayrıca eyaletlerden özel ilgiye muhtaçların evlat edinilmesine yönelik evlat edindirme ödeneği oluşturmalarını teşvik etmişlerdir ve hükümetler evlat edinme giderlerinin yüzde 50 sini karşılamışlardır. Bu amaçla, 1993 yılına kadar, federal hükümet 40 eyalete yüz milyon dolara yakın bir para dağıtmıştır. ${ }^{54}$

1997 yllında, iki partili kongre Adoption and Safe Families Act (ASFA) (Evlat edinme ve Güvenli Aileler Yasası) çıkarmıştır ve bu yasa 1980 yılında çıkan the Adoption Assistance and Child Welfare Act yasasını tadil ederek düzenlemiştir. ASFA Amerika’nın koruyucu aile sistemindeki krize bir tepkiydi. 1996 yılında, yasa yapıcılar koruyucu ailelerdeki çocukların sayısının ikiye katlanarak 500.000'e ulaştığını görerek orijinal yasanın başarısızlığını tespit ettiler ve ilk yasanın birincil amacı olan koruma altındaki çocukların evlat edinen ailelere geçişini sağlayamadığı fark ettiler. ASFAnın bir başka amacı çocukların güvenli olmayan yuvalara yerleştirilmelerini engel olmaktı. 1980 yasasına benzer şekilde, ASFA evlat edinmeyi teşvik için eyaletlere federal fonlar ayırdı. Bu yasa federal politikaların, ailelerin birleştirilmesi ve korunmasından çocuklar için yeni evlat edinecek aileler yaratmaya geçişin bir simgesiydi. ${ }^{55}$

53 A. Kadushin (1980). Child Welfare Services, 3d ed., Macmillan, New York, s. 470.

54 Richard P. Barth, “A Decade Later: Outcomes of Permanency Planning,"in The Adoption Assistance and Child Welfare Act of 1980 (Public Law 96-272): The First Ten Years (St. Paul, Minn.: North American Council on Adoptable Children, 1990); Barth, “Adoption,"51-52.

55 R. Gordon (1999). Drifting Through Byzantium: The Promise and Failure of the Adoption and Safe Families Act of 1997. Minnesota Law Review 83, s. 637-701; N. R.Cahn (1999).Children's Interest in a Familial Context: Poverty,Foster Care, and Adoption. Ohio State Law Journal 60, s. 1189-1190. 
Evlat edinilebilir çocuk sayısında ki düşüusün dördüncü sebebi tartışmalı bir yenilik olan açık evlat edinmedir. Biyolojik annelerin çocukları üzerindeki haklarından feragat etmelerini teşvik etmek amacıyla, sosyal hizmetler uzmanları hamile bayanların doğum sonrası çocuğa kimin annelik yapacağına karar vermeleri uygulamasını başlattı. Sonuç ise açık evlat edinmeydi, bu tür evlat edinmede biyolojik anne ile evlat edinen ailenin kimlik bilgileri değiştirildi ve iki taraf arasında bir kontratın imzalanması sağlandı. 1980lerin ortasına kadar, açık evlat edinme biyolojik anneler ile evlat edinen aileler arasında devamlılık arz eden etkileşim haline dönüştü ve çocuğun büyümesinde iki taraf pay sahibi oldu. Açık evlat edinme artan derecede popülerleşti ve evlat edinmede önemli bir uygulama haline geldi. ${ }^{56}$ Yerleştirme işleminden 2 sene sonra, 1988-1989 yıları boyunca Kaliforniyadaki evlat edinen ailelerin yaklaşı yüzde 55'i çocuklarının biyolojik anneleri ile kontrat imzalamışt. ${ }^{57}$

İdeolojik koruma açık evlat edinmenin başlangıcını işaret etmiştir. Bu tarz evlat edinmenin önde gelenlerinden Reuben Pannor ve Annette Baran geleneksel kapalı evlat edinmelerin, ki bu evlat edinmelerde biyolojik ve evlat edinen aileler birbirlerinden gizlenmiştir, evlatllk çocuklar üzerinde psikolojik problemler doğurduğunu ileri sürmüşlerdir. Evlat edinme hakkı savunucularının önde gelenleri, kapalı evlat edinme sistemlerinin sonunun gelmesi gerektiğini savunmuşlardır. ${ }^{58}$ Açık evlat edindirmeye karşı olanlar onun çocuk üzerinde ne tür etkilerinin olduğunu bilmenin mümkün olmadığını savunmuşlar ve çocukların ideolojik sebeplerden dolayı denek haline getirildiklerini savunmuşlardır. Diğerleri ise iki aile arasında devam eden bir kontratın, çocuğun evlat edinen ailesi ile olan ilişkilerini bozabileceğini iddia etmişler ve ergenler için bağlayıcı kimlik oluşturmalarını zorlaştırdığını savunmuşlardır. ${ }^{59}$ Son dönemde yapılan araştırmalar, çok az sayıda açık evlat edinmenin her iki aileyi de devamlı bir kontrat yoluyla ön plana çıkardığını ve açık evlat edinmenin çocukların sağlıklı psikolojik gelişimlerinde çok az zarara sebep olduğunu savunmaktadırlar. ${ }^{60}$

Evlat edinme hareketinin ortaya çıkışı 1970'de beyaz evlatlık çocuk sayısında düşüşü beraberinde getirdi. Bu hareketin kökleri 1950'lere dayansa da iki defa evlat edinilen eski bir sosyal hizmetler uzmanı Jean M. Paton evlat edinilen çocukların sesi olmaya ömrünü adamış ama evlat edinmeye yönelik haklar 20 sene sonrasına kadar sosyal bir konu haline gelememiştir. Hareketin en sesi çıkan üyesi olan ve New Yorklu bir inşaatçı olan Florence Fisher, 20 yılını biyolojik annesini aramakla geçirmiş ve sonunda onu bulmuştur ve sonra 1971 yllında Adoptees' Liberty Movement Association (ALMA) (Evlatlık Çocukların Özgürlüğü Hareketi Örgütü) örgütünü kurmuştur. Yetişkin yaşlarda olan evlat edinilmiş ama biyolojik ailesini arayan bireylere yardım için, ALMẢnın birincil amacı kapalı kayıtların gizli tutulmasına bir son vermek olmuştur ve yaşı 18’e gelen ve ne sebeple olursa olsun geçmişini öğrenmeyi isteyen her evlatlığa kayıtlarının açılmasını temin etmiştir. Popüler bir kitap olan The Search for Anna Fisher (1973) biyolojik ailesi ile yeniden birleşen bir evlatllğın dramatik hikâyesini ele almıştır ve Fisher bu akımın tartışmasız lideri olmuştur. Böylece ülkede

56 Carp, Family Matters, chap. 7.

57 Barth, s. 55.

58 R. Pannor/A. Baran (1984). Open Adoption as Standard Practice. Child Welfare 63, s. 245-250.

59 Carp, Family Matters, s. 214-215.

60 Barth, s. 55 
evlatlıkların haklarını savunmada en etkili kurum haline gelmiştir. ALMA’nın başarısı Birleşik Devletlerde, Kanada'da ve Birleşik Devletlerde benzer diğer yüzlerce örgütün kurulmasının yolunu açmıştır. 1978 yılına kadar, evlatık çocukları arama gruplarının çoğalmış olması ulusal bir çatı örgütün ortaya çıkmasını doğurmuştur ve adı Amerikan Evlat Edinme Kongresidir. ${ }^{61}$

Evlat edinme aktivistleri, ki bunlar genelde yetişkin yaşa gelmiş evlatlık kişiler ve biyolojik annelerdir, kendilerinin evlat edinme kayıtlarının ortaya çıkarılmasına rızalarının olduğunu ifade etmişlerdir. Mahkeme kararları, eyaletlerin yasal reformları ve eyalet inisiyatifleri yoluyla evlat edinme kayıtlarını gizleyen yasaları kaldırarak kendi ajandalarını takip ettiler. ${ }^{62}$ Eyaletler biyolojik annelerin ki bazılarına gizlilik noktasında söz verilmiştir ve evlat edinilme süreçlerine yönelik kayıtlara erişime sınırsız erişim isteyen yetişkin yaşa erişmiş evlatlıkların kaybedilmekte olan haklarını düzenlemeye çalıştılar. Bunun sonucunda 1990ların ortasına kadar, 17 eyalet mahkemelerin atadığı aracıların kayıtlara erişmesine, biyolojik annelerin yerlerinin tespitine ve onların haklarından feragat ettikleri ve evlatlık verdikleri çocukları ile yeniden bir araya gelmeye ilgilerinin olup olmadığını araştırmasına izin verdi. Dahası, 19 eyalet formal karşılıklı evlat edinme rıza formu oluşturdular. Böylece hem biyolojik anne hem de evlat edinen aileler isimlerini kaydedebilme şansı verildi: Her iki taraf kayıt olursa, kendileri olası riza uyumundan haberdar edilir ve böylece bir buluşma organize edilir. 6 eyalet ise herhangi bir kayıt işlemine gerek olmaksızın hem evlat edinilen kişi ile hem de biyolojik annenin rızası alınarak kayıtlardaki bilgilerin paylaşılmasına izin verdi. ${ }^{63}$ Gelişmeler evlat edinenlerin ilgili kayıtlara erişmesine doğru bir değişime doğru giden bir yolu işaret etmektedir. Oregon, Tennessee, Delaware ve Alabama eyaletleri evlat edinilen kişilerin orijinal doğum sertifikalarına erişimlerine izin verme konusunda Kansas ve Alaska eyaletlerine katıldılar ve CWLA'nin 2000 evlat edindirme standardı üye ajanslara yetişkin yaşa ulaşmış evlatlık çocuklara evlat edinilme süreçleri ve biyolojik annelerine ulaşmaları noktasında destek sunmalarını tavsiye etmektedir. ${ }^{64}$

\section{EVLAT EDINMENIN GENEL OLARAK DÜZENLENMESi}

Amerikan hukukunda evlat edinmeye ilişkin bazı özel hususlar mevcuttur. Bunlardan biri "equitable adoption" olarak ifade edilen hukuksal yöntemdir. ${ }^{65}$ Birçok eyalette bu yöntem kabul görmüştür. Bu tür evlat edinme, Alman ve İsviçre hukuklarında ve Türk hukukunda yer almayan, tamamen common law etkisiyle kabul edilen bir evlat edinme türüdür. Bu evlat edinme yönteminde, aslında evlat edinmeye ilişkin yasal şartlar yerine getirilmeksizin mahkeme tarafından ana ve baba ile çocuk arasında kurulan ilişkinin evlat edinme olarak nitelendirilmesi ve buna ilişkin bazı sonuçlar

61 Carp, Family Matters, s. 214-215.

62 Carp, Family Matters, s. 214-215.

63 J. H. Hollinger, “Aftermath of Adoption: Legal and Social Consequences,"in Adoption Law and Practice, 1995 supp.,ed. Hollinger et al.(New York: Matthew Bender, 1995), 2:51, app. 13-A.

64 CWLA, Standards of Excellence for Adoption Services, rev. ed. (Washington, D.C.: CWLA, 2000 ), 89.

65 Kuntz, 2013, a.g.k., 113; Güvercin, s. 107. Bu evlat edinme yöntemi "de facto adoption", "virtual adoption" olarak da ifade edilmektedir. R.C.Bell (1999). Virtual Adoption: The Diffuculty of creating an exception to the Statury Scheme. Stetson Law Reiew. Vol. XXIX, s. 416. 
ortaya çıkarması söz konusudur. ${ }^{66}$ Dolayısıyla mahkeme içtihadına dayalı olarak kurulan bir ilişki mevcuttur.

Equitable adoption yönteminde, aralarında evlat edinme ilişkisi kuran bir mahkeme kararı bulunmayan anne ve baba ile çocuğun, sanki çocuk kendilerinin çocuğuymuş gibi davranmaları söz konusudur. ${ }^{67}$ Mahkeme bu tür evlat edinmeye karar verirken, kararını ya sözleşme teorisine ya da esstoppel teorisine dayandırmaktadır. Sözleşme teorisinde, mahkeme, evlat edinenin çocuğu aralarındaki sözleşmeyle resmi olarak etkili bir şekilde evlat edinmeyi kabul ettiğini varsaymaktadır. ${ }^{68}$ Equitable adoption ancak evlat edinenin ölümünden sonra ileri sürülebilir. ${ }^{69}$ Sözleşme teorisi, çocuğun sözleşme yapan taraf olup olmadığı veya doğal ebeveynler (ana-baba) ile evlat edinenler arasında yapılan sözleşmenin üçüncü taraf lehtarı olup olmadığı sorusunu gündeme getirmektedir.

Estoppel teorisi ise, equity hukukundan doğan bir kurumdur ve taraflardan birinin diğerini yanlış söz ve davranışlarla etkileyerek belirli bir harekette bulunmasını sağlayarak fayda elde etmesini önlemektedir. ${ }^{70}$ Estoppel doktrini, equitable adoption'ın inkâr edilmesi halinde, çocuğun evlat edinildiğinin iddia etmek amacıyla tanınmış bir hukuki çaredir. ${ }^{71}$

Equitable adoption, resmi şekilde kurulan evlat edinmeyle aynı sonuçları doğurmamaktadır. ${ }^{72}$ Doğurduğu sonuçlardan biri, çocuk kendisini evlat edinen kişinin yasal mirasçısı gibi onun mirasına hak kazanır. Bu kurumda asıl özellik arz eden durum, vasiyetname bırakmaksızın ölen evlat edinene, tamamen yabancı olan (akrabalık ilişkisi bulunmayan) bir kişinin tıpkı yasal bir mirasçı gibi mirasçı olmasıdır. ${ }^{73}$ Bu tür evlat edinmede çocuk ile onu kabul eden yani bir anlamda evlat edinen kişi arasında ebeveyn-çocuk ilişkisi kurulmaz. Bunun dışında, evlat edinilen çocuk ile öz ailesi arasındaki hısımlık ilişkisi devam etmektedir.

Evlat edinmeyi düzenleyen federal model yasada, evlat edinme aracı kuruluşlar eliyle gerçekleştirilebileceği ${ }^{74}$ gibi evlat edinecek aile ile çocuğunu evlatlık alacak ailenin karşılıklı olarak aracı kurum olmaksızın evlat edinme işlemini gerçekleştirebilecekleri ${ }^{75}$ ifade edilmektedir. Bunun dışında ülkelerarası evlat edinmeye (intercountry adoption) de izin verilmektedir. ${ }^{76}$

66 Kuntz, 2013, a.g.k., 113 vd.; Güvercin, s. 107.

67 Bell, 1999, a.g.k., 416.

68 J.E.Rein (1984). Relatives by Blood, Adoption, and Association: Who Should Get What and Why (The Impact of Adoptions, Adult Adoptions, and Equitable Adoptions on Instate Succession and Class Gifts). 37 Vanderbilt Law Rewiew. 711, s. 770; Kuntz, 2013, a.g.k., 114. Taraflar arasındaki bu sözleşme açık ya da zımni şekilde gerçekleştirilebilmektedir.

69 Kuntz, 2013, a.g.k., 114.

70 B.A.Garner (2009). Black's Law Dictionary, s. 629-630; Kuntz, 2013, a.g.k., 115; Güvercin, s. 109-110.

71 Güvercin, s. 110; Kuntz, 2013, a.g.k., 116. Estoppel genellikle çocuğu bakıp gözeten kişinin ölmesinden sonra ortaya çıkar. Böyle bir durumda bakılmış olan çocuğun miras hakkından yoksun bırakılmasının önüne geçilmiş olunmaktadır. Equitable adoption'1 kabul eden eyalatler, Alabama, Alaska, Arizona, Kansas, Washington DC'dir.

72 W.M.Mcgovern, S.F.Kurtz ve J.E.Rein (1988). Wills, Trusts, and Estates. Including Taxation and Future Interests. St. Paul, Minnesota, s. 56; Kuntz, 2013, a.g.k., 121.

73 Bu etkisiyle bu kurumun tamamen çocuğun lehine sonuç çıkardığını söylemek mümkündür. Kuntz, 2013, a.g.k., 121.

74 Buna Domestic agency adoption adı verilmektedir.

75 Bu tür evlat edinme işleminde domestic indepedent (non-agency) adoption kavramı kullanılmaktadır.

76 Güvercin, s. 75; Kuntz, 2013, a.g.k., 141 vd. 
Amerikan evlat edinme hukukunda open adoption (açık evlat edinme) ile closed adoption (kapalı evlat edinme) ayrımı da bulunmaktadır. Açık evlat edinmede, doğum yapan anne yani doğal anne çocuğunu evlatlık olarak vereceği kişiyi ya da aileyi seçme hakkına sahiptir. ${ }^{77}$ Kapalı evlat edinmede ise, doğum yapan anne yani biyolojik anne evlat edinme sürecini yönetemez; çocuğu üzerindeki tüm hakları kaybeder ve çocukla ilgili tüm süreç artık yetkili kamu kuruluşunun bünyesinde gerçekleştirilmektedir. Bu tür evlat edinmede biyolojik anne ile müstakbel evlat edinen kişi ya da aile arasında hiçbir etkileşim bulunmamaktadır. ${ }^{78}$

\section{VERMONT EYALETININ EVLAT EDINMEYE ILIŞKIN GETIRDiĞi DÜZENLEME}

Amerika Birleşik Devletleri'nin Vermont eyaletinin evlat edinmeye ilişkin düzenlemeleri Uniform Adoption Act'i anlamak bakımından önem taşımaktadır; çünkü bu Act'i kabul eden tek eyalettir. 15A maddesi, Adoption Act'te evlat edinme kurumu düzenlenmiştir. Kanunun birinci bölümü genel hükümlerden oluşmaktadır. Öncelikle Kanunda geçen ifadelerden ne anlaşılması gerektiğine ilişkin olarak "Tanımlar" kısmı yer almaktadır. ${ }^{79}$

77 L. Gaddie (2009). Open Adoption. Journal of the American Academy of Matrimonial Lawyers. Vol. 22, s. 501 vd.; E.Gray (2009). Open versus Closed Adoption. The Journal of Undergraduate Nursing Writing. Volume 3, Number 1, s. 27. Ayrıca genel bilgi için bkz. https://www.law.cornell.edu/wex/adoption

78 Gray, s. 28. Bu konuda bkz. https://americanpregnancy.org/adoption/closed-adoption-advantages/

79 Bölüm 1: Genel Hükümler \$1-101. Tanımlar

Bu başlıkta kullanıldı̆̆ı gibi:

1) Evlatlık, evlat edinilen veya evlat edinilecek kişi anlamına gelir.

2) Yetişkin, 18 yaşını doldurmuş kişi demektir.

3) Ajans(acente), evlat edinilmeleri için küçükleri yerleştiren, eyalet tarafından lisanslı "Departman” veya özel ve kamu çocuk yerleştirme kurumu anlamına gelir.

4) Çocuk; doğumla veya evlat edinmeyle, küçük veya yetişkin, oğul veya kız anlamına gelir.

5) Özel ihtiyaçları olan çocuk; etnik yapı, azınlık veya kardeş grubun üyesi olma, sağlık durumu veya fiziksel-zihinselduygusal engel gibi durumlar da dahil olmak üzere özel koşullara sahip olan ve bu nedenle sağlıksal veya evlat edinmeye ilişkin yardım sağlamadan evlat edinenin yanına yerleştirmenin makul olmayacağı çocuktur.

6) "mahkeme", bu eyaletin mahkemesine atıfla, yüksek mahkemenin ölümden sonraki hukuki prosedürleri(vasiyetname gibi) inceleyen bölümüdür.

7) "Departman", çocuk ve aileler departmanı anlamına gelir.

8) Önceki ana-baba(parent), iradi veya irade dışı şekilde hakları sona erdirilen, evlat edinilenin ana-baba(parent)idir.

9) "Vasi” başka bireyler için ana-baba(parent) gibi hareket eden ve mahkeme tarafından evlat edinilmeleri için küçükleri yerleştiren, özel olarak yetkilendirilmiş ana-baba(parent) dışındaki kişidir.

10) "tanımlayıcı bilgi", eski ana-baba(parent)inin veya aile üyesinin, tam isim, doğum yeri ve tarihi, son bilinen adresi de dahil olmak üzere mevcut-güncel yerini belirleyebilecek herhangi bilgi anlamına gelir.

11) "Yasal Velayet"(Yasal koruma) hukuken izin verildiği şekilde küçüğün genel denetimini devam ettiren hak ve görev anlamına gelir. "yasal velayet”; küçüğü koruma, eğitme, terbiye etme ve küçüğe yemek, kıyafet, barınma, sağlıksal bakım ve destekleyici çevre sağlama hak ve görevlerini de içerir.

12) Küçük, henüz 18 yaşını doldurmamış kişidir.

13) Ana-baba(parent), bu belgenin 2-401(a)(1)-(4) veya 6 alt bölümü uyarınca küçüğün evlat edinilmesi için rızası gereken veya hukuken ana veya baba olarak tanınan kimsedir.

14) Fiziksel velayet(fiziksel kısıtlılık), küçüğün fiziksel denetimi ve fiziksel bakımı anlamına gelir.

15( "evlatlık verilmek üzere yerleştirme" (place for adoption) küçügü evlat edinecek müstakbel-olası evlat edinecek ana-baba(parent)i seçmek ve evlat edinene küçüğün fiziksel velayetini müstakbel-olası evlat edinene transfer etmek anlamina gelir.

16) "kayıtlar", evlat edinmeye karar verilmesinden önce veya sonra toplanan, evlat edinme ile ilgili bütün belge, kanıt- 
Bu Kanun uyarınca, çocukla ana ve baba arasında ilişki kurmak amacıyla herkes evlat edinebilir ve başkası tarafından evlat edinilebilir. Bir aile, eğer bir ana/baba ve onun partnerinden oluşuyorsa ve evlat edinme çocuğun üstün yararına hizmet edecekse, partner durumundaki kişi diğerinin çocuğunu evlat edinebilir. ${ }^{80}$

Evlat edinme, mahkeme kararı ile gerçekleşmektedir. Evlatlığın evlat edinmeden sonra adının ne olacağı hususunda mahkeme kararında belirtilen hususlar geçerli olacaktır. Dolayısıyla evlat edinme kararında eğer evlatlığın adının değişeceği hükmü yer almışsa bu hüküm uygulanacak; aksi takdirde evlatlığın adı aynı kalacaktır. Evlat edinme kararının verilmesiyle birlikte evlatlık ile evlat edinen arasında nasıl bir hukuki ilişki meydana geleceği Kanunun \$1-104. maddesinde düzenlenmiştir. Evlat edinme hükmünün kesinleşmesiyle evlat edinilen çocukla evlat edinen arasında tıpkı ana-baba ile çocuk arasında mevcut olan ilişki gerçekleşmektedir. Evlat edinen ile evlatlık arasında, miras hakkı, birbirlerine halef olma ve hısımlık ilişkisi doğmaktadır. Evlat edinen ana babanın sahip olduğu hak ve yükümlülüklere sahip olmaktadır.

Evlat edinmeye ilişkin mahkeme kararı kesinleştiğinde; çocuk desteği için vadesi gelmiş ödemeleri yapma görevi hariç - miras hakkı ve vasiyetname yapmadan ölen evlatlığa mirasçı olma hakkı da dâhil olmak üzere velayete ilişkin bütün haklar ve görevler, her bir eski veli için, sona erer. ${ }^{81}$ Eski ana baba velayet hakkının sürdürülmesini talep etmek isterse, Kanunun \$1-110 - maddesi uyarınca bazı şartları yerine getirmek zorundadır. Buna göre, herhangi bir zamanda, bu eyalette doğmuş

gösterge ve bilgilerdir.

17) "Sicil", departman tarafından yürütülen evlat edinme sicilidir.

18) "akraba”; yakınlık, tam veya yarım kan evlat edinmeyle kişiye bağlı olan; kişinin büyükanne, büyükbaba, büyükbüyük anne-baba, kardeş, ilk derece kuzenler, hala, teyze, büyük hala, büyük teyze, yeğenidir. Üvey ana-baba, akraba değildir.

19) "feragat etme-vazgeçme", küçüğün ana-baba(parent) veya vasisi tarafından, küçüğün evlat edinilmesi amacıyla, yasal ve fiziksel velayeti de dahil olmak üzere küçük ile ilgili olarak ana-baba(parent) ve vasi haklarının bir ajansa gönüllü olarak teslim etme anlamına gelir.

20) “Kardeş” tam veya yarım(kan) erkek kardeş veya kız kardeştir.

21) "State", Amerika Birleşik Devletleri, Columbia Bölgesi, Porto Riko Ulusu veya Amerika Birleşik Devletleri’nin yargı yetkisine tabi herhangi bölge veya bağımsız yer anlamına gelir. 22. alt başlık 1 Temmuz 2019'a kadar geçerlidir; ayrıca 22.alt başlı̆̆a bakınız.

22) Üvey ana-baba; çocuğun ana-baba(parent)inin eşi veya sağ kalan eşi olan ama çocuğun ana-baba(parent)i olmayan kişidir. 22. alt başlık 1 Temmuz 2019’a kadar geçerlidir; ayrıca 22.alt başlığa bakınız.

23) State sicil memuru ve hayati-önemli kayıtların sicil memuru; Sağlık Departmanı’ndaki Hayati Kayıtlar Ofisi’nin denetmeni’dir. 23. alt başlık 1 Temmuz 2019’a kadar geçerlidir; ayrıca 23.alt başlığa bakınız.

24) Hayati-önemli kayıtların denetmeni, Sağlık Departmanı’nın hayati kayıtlarının denetmenidir. 23. alt başlık 1 Temmuz 2019'a kadar geçerlidir; ayrıca 23.alt başlığa bakınız.

25) Üvey ana-baba, bir çocuğun ana-baba(parent)inin eşi veya hayatta kalan; ancak çocuğun ana-baba(parent)i olmayan kişidir.

80 Burada bahsedilen İsviçre, Alman veTürk hukuklarında da kabul edilen üvey evlat edinmedir.

81 1) Bir evlatlı̆̆ın her bir vasiyetname yapmadan ölen eski veliye mirasçı olma hakkı ve her bir eski veliye kan hısımlığı sona erer ve

2) Doküman aşağıdakileri içermedikçe; evlat edinilen eski ana-baba’nın çocuğu, altsoyu, mirasçısı değildir.

A)Açıça aksi yönde irade bildirirse veya

B)Evlatlı̆̆ ismen veya onu tanımlayan başka yollarla içerirse.

Ayrıca eğer bağışlama belgesi (3)(B) bölümünün (a) fikrasındaki gibi bir evlatlık içeriyorsa, evlat edinmeye ilişkin kamusal vasi(saklayan), evlatlığın yerinin ve kimliğinin tespitine yardım etmek için, bilgileri, Yüksek Mahkeme’nin ölüme bağlı tasarruflarla ilgili dairesine gönderme yetkisi vardır. 
çocuğa velisi veya velisi olduğu iddia edilen kişi; velayet haklarının devamı iradesi bildirimi için, bu eyaletteki Yüksek Mahkeme’nin herhangi ölüme bağlı hukuki sonuçlarla ilgilenen dairesine talepte bulunabilir (dava açabilir). ${ }^{82}$

Kanun ikinci bölümüyle küçüklerin evlat edinilmesini düzenlemiştir. Küçüklerin evlat edinilmesinde bu küçüklerin evlat edinilmeleri amacıyla onları evlat edinmek isteyen kişi ya da kişilerin yanına yerleştirilmesi söz konusu olmaktadır. Bu yerleştirmenin altında yatan temel neden ise, yanına müstakbel evlatlık yerleştirilen kişilerin evlat edinmeye uygun olup olmadığının, çocukla ebeveyn ilişkisi içine girip giremeyeceğinin tespitini yapmaktır. Yapılan yerleştirme sonunda bu tespitin gerçekleşmesi için bir değerlendirici atanır ve ondan görüş istenir. Değerlendiricinin yapması gereken evlat edinmek isteyen kişinin bir ebeveyn olarak uygun olup olmadığını değerlendirmek ve buna ilişkin bir rapor hazırlamaktır. Bu rapor ilgili bölüme ve yanına yerleştirme yapılan kişiye verilmektedir. Evlat edinmek isteyen kişinin bu rapora (değerlendirmeye) itiraz etme hakkı mevcuttur. 83

Küçüklerin evlat edinilmesinde, evlat edinmeye rızası aranan bazı kişiler bulunmaktadır. Buna göre,

- çocuğu doğuran kadının

- $\quad$ ana tarafından ya da mahkemede başka yollarla tespit edilen biyolojik babanın

- Bir küçük eğer evlilik içinde veya evliliğin sona ermesinden itibaren ya da mahkemece ayrılığa hükmedilmesinden itibaren 300 gün içinde doğmuş ise, ana ve babanın

- Vasinin

- mevcut evlat edinenin veya yasal olarak tanınan diğer anne ve küçüklerin babasının

rızası aranmaktadır. Rızası aranan kişiler nasıl hüküm altına alınmışsa, evlat edinmeye izni aranmayanlar da yasal olarak düzenlenmiştir. Bunlar, evlat edinme hakkını içeren ebeveyn (ana ve baba) haklarını veya vesayet yetkisini, bu maddenin bu kısmına göre bir ajansa bırakanlar; küçükle ebeveyn ilişkisi hukuki olarak sonlandırılmış veya var olmayacağına karar verilen bir kişilerdir.

Bir ebeveyn (ana baba) veya vasi tarafından istenen bir rıza veya vazgeçme, tamamen İngilizce olarak veya veli veya velisinin anadili İngilizceden farklı bir dil ise, o dilde yazılı olmalı ve bazı bilgi ve belgeleri içermelidir. ${ }^{84}$

82 Yüksek Mahkemenin ölüme bağlı işlerle ilgilenen her bölümü; (a) alt başlı̆̆ı altında bu mahkemeye sunulan bildirimi, bu tür bütün bildirimler için merkezi muhafaza deposu gibi hizmet verecek Chittenden Bölgesi’nde bulunan Yüksek Mahkeme’nin ölüme bağlı işlemlerle ilgilenen bölümüne iletecektir. Bu eyalette bir küçüğü evlat edinme dilekçesi verilirse, Yüksek Mahkeme’nin ölüme bağlı hukuki sonuçlarla ilgili bölümünün sicili, bu bölüme göre çocuğun evlat edinilmesine ilişkin bildirimde bulunulup bulunulmadığını dilekçe tarihinden itibaren belirleyecektir.

$83 \$ 2-206$. Review of evaluation

(a) Within 90 days after a person receives a preplacement evaluation with a finding that he or she is not suited to be an adoptive parent, the person may petition the probate division of the superior court for review of the evaluation. ( Bir kişi, evlat edinen bir ebeveyn olmaya uygun olmadığını belirten bir ön değerlendirme değerlendirmesini aldıktan sonraki 90 gün içinde, değerlendirmenin gözden geçirilmesi için üst mahkemenin vekil bölümüne vekâlet edebilir).

84 2-406. Rıza veya vazgeçme içeriği

(a) Bu başlık altındaki bir ebeveyn veya vasi tarafından istenen bir rıza veya vazgeçme, tamamen İngilizce olarak veya veli 
Kanunun beşinci bölümünde yetişkinlerin ve özgür bireylerin ${ }^{85}$ evlat edinilmesi düzenlenmiştir. Buna göre yetişkin bir birey başka yetişkin bir bireyi ya da özgür bir bireyi evlat edinme hakkına sahiptir. Bu tür evlat edinmelerde bazı kişilerin evlat edinmeye rızası aranmaktadır. Özgür bir bireyin veya yetişkinin evlat edinilmesine dair rıza sadece koruyucu anne ve babaların eşlerinden alınmaktadır, yasal olarak ayrı olmadıkları sürece veya mahkeme eşin rızasının alınmasının mümkün olmadığı kanaatine varır ise veya rıza hakkını saklı tutarak evlatlı̆̆ın veya evlat edinen koruyucu ailenin çıkarlarını kollayarak bu kararı verebilir. Evlat edinme adayı bir anne/bana ve evlatlık birlikte evlat edinmeye yönelik bir dava başvurusunda bulunabilir. Dava dilekçesi her bir davacı tarafından imzalanmalı, tasdik edilmelidir. ${ }^{86}$

Dava açıldıktan sonra makul bir gerekçe olmadığı sürece, her iki davacı da şahsen mevcut olmak durumundadırlar. Daha sonraki süreçte davacılara ayrı ayrı veya birlikte bildirimde bulunulabilir ve bildirim yetkili bir avukatın eşliğinde tutanak altına alınmalıdır. Bildirim telefon ya da başka elektronik araçla ya da yapılabilmektedir. Mahkeme, davacıları veya davacıların bulunmadığı durumlarda yetkili avukat kanalı ile inceleyecek veya eğer aşağıda verilen şu koşulları tespit ederse evlat edinme yönünde karar verecektir:

veya velisinin anadili İngilizce'den farklı bir dil ise, o dilde yazılı olmalı ve içermelidir: (1) rıza veya fesih işlemini yapan bireyin adı, doğum tarihi ve mevcut posta adresi; (2) doğum tarihi ve küçük evlat edinenin adı; (3) bir rrza, rızayı yürüten bireyin reşit olmayanı evlat edinmeye yerleştirmek veya yerleştirmek niyetinde olan müstakbel evlat edinen ebeveyni temsil eden avukatın adı, adresi ve telefon numarası; (4) vazgeçilmesi halinde, reşit olmayan görevlinin görevden alındığı kurumun adı, adresi ve telefon numarası; (5) rızanın veya vazgeçilmenin nasıl iptal edileceği ve bir kenara bırakma eyleminin nasıl başlatılacağına ilişkin özel talimatlar; (6) evlat edinme dilekçesinin verildiği ya da sunulacağı ya da eğer bilmediği hallerde, mahkemenin adı ve adresi, ya da eğer bilinmiyorsa, dolandırıclık veya zorlama durumlarında harekete geçilecek bir mahkemenin adı ve adresi

85 "Emancipated" ifadesini özgür birey olarak çevirmeyi doğru bulduk. Bu ifade çocukların ebeveynlerinin otoritesinden serbest bırakılıp önemli yasal amaçlarla yetişkin sayılmasını karşılamaktadır. Aslında tam karşılı̆ı olmasa da Türk hukukundaki erginlik yaşını doldurmaksızın (aslında hala yaş bakımından küçük olan) mahkeme kararı ile ya da evlenme ile erginliğin kazanılmasından sonra kişilerin ergin sayılarak yapacakları işlemlerde serbest olmaları durumuna yaklaşık bir durum söz konusudur. Bu hususta şu tanıma bakılabilir: https://www.law.cornell.edu/wex/table_emancipation (Erişim tarihi: 01.03.2019).

86 Dava dilekçesi her bir davacı tarafından imzalanmalı, tasdik edilmeli ve dilekçede

(1) tam isim, doğum tarihi, her bir davacının ikameti yeri ve ikamet etme süreleri belirtilmeli;

(2) her davacının mevcut medeni durumları, evlenme yerleri ve evlenme tarihleri kapsayacak şekilde, eğer evliler ise, belirtilmelidir;

(3) evlatllğa yönelik bilinen tam isim daha söz konusu ise;

(4) evlat edinilen birey ile olası evlatlık edinme adayı anne/aba arasındaki ilişkinin doğası ve süresi belirtilmeli;

(5) Evlat edinme adayı anne/baba ve evlat edinilenin yasal anne çocuk ilişkisi talebi ifade edilmeli ve bu ilişkinin doğasının doğurduğu tüm haklara yönelik talepler ifade edilmelidir;

(6) Evlatlığın mevcut bir anne baba var ise onunla olan ilişkilerinin ve bağlarının ortadan kalması sonucunu doğuracağını anladığını ifade etmesi, fakat evlat edinen aile eğer evlatlığın üvey anneleri ise evlat edinme işleminin evlatlığın üvey annenin eşi olan anne/baba ile olan ilişkisini etkilemeyeceğini fakat evlatlığın diğer anne/babası ile olan ilişkisini ortadan kaldıracağını anladığını ifade etmesi gerekmektedir, bu anne/babadan veya o anne/baba yolu şile miras hakları hariç.

(7) evlatlık ile evlat edinme adayı anne/baba evlat edinme işleminin sonuçlarının mülkiyet ve miras haklarına yönelik bazı sonuçlar doğurabileceğini kabul eder veya;

(8) rizası gereken her hangi bir bireyin bilinen en son adresi ve ismi ifade edilmeli;

(9) evlat edinme adayı anne/babanın her hangi bir çocuğunun bilinen son adresi ve ismini, hatta daha evvelden aday anne/baba tarafından evlat edinilmiş çocuğun bilgileri veya eşinin bilgileri, evlat edinme yeri ve yllı belirtilmelidir ve;

(10) evlat edinilen kişinin çocuğu veya hayatta olan anne/babasının bilinen son adresi, adı ve yaşı belirtilmelidir. 
(1) evlat edinme davasının taraflara bildirilmesinin üzerinden en az 30 gün geçmiş ise

(2) davaya yönelik rızanın 5-103 maddeye göre alınması gereken kişilere bildirimin yapıldığının tespit edilmesi;

(3) tarafların rızası, feragati veya gerekli tüm belgelerin, yargılamaya yönelik tüm evrakların mevcut olduğunun ve dosyaya konulduğunun tespit edilmesi durumunda;

(4) evlat edinmenin davacılar arasında anne/baba çocuk ilişkisinin yaratılması amaçlı olduğunun görülmesi ve davacıların kurulacak bu ilişkinin doğuracağı sonuçları anladıklarının görülmesi durumunda ve

(5) Bu yasa maddesine yönelik bir uyumun söz konusu oluğunun görülmesi durumunda.

Gerek ergin olmayanların gerekse ergin ve özgür bireylerin evlat edinilmesinde, aranan şartların sağlanmış olması ve evlat edinecek kişi ya da ailenin evlat edinmeye uygun olduğunun anlaşılması ile mahkeme tarafindan evlat edinmeye karar verilmektedir.

Evlat edinme bakımından pek çok eyalette ortak olan genel bazı kurallar da bulunmaktadır. Genel olarak eyaletler hukukunda evli olmayan kişilerin ile evli eşlerin birlikte evlat edinmesine izin verilmiştir. Evlat edinebilecek olanlar ise, eyaletler bakımından genelde çocuklardır. Erginlik yaşı ise eyaletlere göre değişmekte olsa da genelde 18 yaşından küçüklerin çocuk sayıldığı görülmektedir. Ancak yaş sınırı olmaksızın pek çok eyalette kişilerin evlat edinilmesi mümkündür. Evlat edinme amacıyla kişinin yerleştirilmesinde ise bazı eyaletlerde aracı kurum yetkili iken, bazı eyaletlerde hem aracı kurum hem kişinin anne babası, bazı eyaletlerde ise sadece ana baba yetkili olarak kabul edilmiştir. $^{87}$

Evlat edinme kararını verme hususunda hangi mahkemelerin görevli olduğu ise, her eyalet kanunu düzenlemesine göre değişmekte; görevli olan mahkemeler ise eyaletlere göre şu şekilde adlandırılmakta ve belirtilmektedir ${ }^{88}$ :

- $\quad$ Circuit Court

- District Court (Bölge mahkemesi)

- $\quad$ Superior Court (Temyiz mahkemesi)

- $\quad$ Probate Court (Mirasla ilgili olan mahkeme) $)^{89}$

- $\quad$ Family Court (Aile mahkemesi)

- Juvenile Court (Çocuk mahkemesi)

87 Güvercin, s. 88. Ayrica bkz. https://www.childwelfare.gov/pubpdfs/jurisdiction.pdf

88 Bunun için bkz. https://www.childwelfare.gov/pubpdfs/jurisdiction.pdf

89 Veraset mahkemesi olarak çeviren yazarlar da bulunmaktadır. Bkz. Güvercin, s. 90. Ancak bu mahkeme sadece veraset işleri ile ilgilenen bir mahkeme olmadığ 1 için mirasla ilgili işlere bakan mahkeme olarak çevirmeyi daha doğru bulduk. 
Evlat edinme kararı vermeye yetkili olan mahkeme ise, genelde evlat edinme başvurusu yapan kişi ya da kişilerin oturduğu yer veya evlatlık alınacak çocuğun ikamet ettiği yer yahut çocuğun yerleştirildiği kuruluşun bulunduğu yer mahkemesidir. ${ }^{90}$

Evlat edinmeye rızası aranan kişilerin başında çocuğun biyolojik ana babası ile çocuğun kendisi gelmektedir. ${ }^{91}$ Rızanın verilme zamanına ilişkin eyaletlerde ortak süreden bahsedilemez. Yaklaşık 47 eyalette çocuğun öz ana babasının evlat edinmeye verecekleri rıza için belirli süre öngörülmüştür. ${ }^{92}$ Vermont eyaletinde bu süre 36 saat olarak kabul edilmiștir. ${ }^{93}$

Verilecek rızanın şeklinin nasıl olacağı sorusunun cevabı her eyalet bakımından kendi yasalarında ayrıca düzenlenmiş olsa da birçok eyalette rızanın yazılı olarak tanıklar ve/veya noter önünde verilmesi gerekmektedir. ${ }^{94}$

Evlat edinme için aranan tüm şartların gerçekleşmesiyle mahkeme evlat edinmeye karar vermektedir. Burada hâkimin takdir yetkisi Türk hukukundan farklı olarak daha geniş olarak karşımıza çıkmaktadır. ${ }^{95}$ Hâkim evlat edinme kararı vermeden önce yaptığı duruşmayla evlat edinmek isteyen kişinin ya da eşlerin bir çocuğu yetiştirmeye elverişli yapıda olup olmadığını inceler. ${ }^{96}$ Yapılan inceleme sonunda hâkim ya evlat edinme talebini reddeder ya da kabul ederek evlat edinmeye karar verir.

Evlat edinme kararı verilmesiyle ana ve babaya ait olan haklar ve yükümlülükler artık evlat edinene ait olmaktadır. Pek çok eyalette evlatlık, evlat edinme kararı sonrasında evlat edinenin soyadını alabilmektedir. Ancak evlat edinenler çocuğun öz ana ve babasının soyadını taşımaya devam etmesini isteyebilirler; böyle bir durumda da bu hususta mahkemeden karar almaları gerekmektedir. Bunun dişında eyaletlerin birçoğunda evlatlık evlat edinene mirasçı olmakta; Türk hukukundan

90 Venue refers to the geographic location of the court that will hear the case. Most states, Puerto Rico, and the Virgin Islands maintain courts of all types located in counties or districts throughout the state or territory.10 Petitions for adoption are filed in the type of court that has the appropriate jurisdiction at the location (or venue) that is convenient to the parties involved in the case. In many cases, there is a residency requirement. In many states, venue options include the county in which the person seeking to adopt (petitioner) resides or is in military service, where the child to be adopted resides, or where the child-placing agency is located. Other venue options include the county where parental rights were terminated (Louisiana and New York) or the county in which the placing birth parent(s) lived when the placement agreement was signed, the child was freed for adoption, or the adoption petition was filed (California). Bkz. https://www.childwelfare.gov/pubpdfs/jurisdiction.pdf

$91 \mathrm{https} / /$ www.chidwelfare.gov/pubPDFs/consent.pdf\#page=2\&view=Who\%20must\%20consent? Yaklaşık 25 eyalette ve Virjinya Adalarında 14 yaşındaki çocukların evlat edinmeye rıza göstermeleri gerekmektedir. 19 eyalette ve Amerikan Samoa ve Guam’da bu yaş sınırı 12 olarak kabul edilmiştir.

92 Birçok eyalette rızanın verilebilmesi bakımından bekleme süresi öngörülmüștür. Bu bekleme süresi pek çok eyalette 72 saat veya 3 gün olarak belirtilmiştir. En kısa bekleme süresinin 12 (Kansas) ve 24 saat (Utah); en uzun bekleme süresinin 10 (Virjinya ve Washington) ve 15 gün (Rhode Island) olarak kabul edildiği görülmektedir. Detaylı bilgi için bkz. https:// www.childwelfare.gov/pubPDFs/consent.pdf\#page $=2 \&$ view $=$ Who $\% 20$ must $\% 20$ consent?

$93 \mathrm{https} / /$ www.childwelfare.gov/pubPDFs/consent.pdf\#page=2\&view=Who\%20must\%20consent?

94 Yaklaşı 21 eyalette, Amerikan Samoa, Guam, Virjinya Adalarında, Kuzey Mariana Adalarında ve Porto Ricoda bu husus geçerlidir. Bkz. https://www.childwelfare.gov/pubPDFs/consent.pdf\#page=2\&vie w=Who\%20must\%20consent?

95 Y. Altuğ (1957). Türk ve Birleşik Amerika Devletleri Hukukunda Evlat Edinme Üzerinde Bir İnceleme. İÜHFD, 22(1-4). İstanbul, s. 246.

96 Bu inceleme genellikle kapalı oturumda ya da bizzat hâkimin kendi odasında yapılır. Bu konuda bkz. Altuğ, s. 246. 
farklı olarak ise bazı eyaletlerde evlat edinenin de evlatlıktan miras almasına imkân tanınmaktadır. ${ }^{97}$ Yine Türk hukukundan farklı bir düzenleme olarak, genellikle evlatlı̆̆ın öz ana ve babasından miras alamaması durumunda söz konusu olabilmektedir. ${ }^{98}$ Türk hukukuyla ortak olan durum ise evlatllğın sadece evlat edinene mirasçı olması hususudur.

\section{SONUÇ}

Amerikan evlat edinme uygulamaları geçmiş 250 yılda radikal şekilde değişmiştir. İlk başlarda informal olarak başlayan ve acemilik aşamalarından geçen evlat edinme uygulamaları 50 farklı eyalette hükümetlerce yönetilen ve federal katılım giderek arttığı yasal bir kurum haline gelmiştir. Geçen yüzyılda, sosyal hizmetler uzmanları profesyonelleşmiş ve Birleşik Devletler Çocuk Bürosu ve CWLA evlat edinmeyi düzenlemek için tekdüze standartlar oluşturmuşlardır. 2. Dünya savaşından beridir, evlat edinme, yabancı, azınlık, yaşlı, fiziksel ve zihinsel engellilerin ve HIV pozitif olan çocukların evlat edinilmesini sınırlayan elitist bir kurumdan dönüşerek mevcut halini almıştır. Dahası, geçmişteki 50 yıllık süreç gizli evlat edinme uygulamasından açık evlat edinme sistemine ve aynı zamanda evlat edinilen çocukların biyolojik aileleriyle birleştirilmesine yönelik bir eğilim almıştır. Internet son yıllarda evlat edinilmiş çocukların biyolojik aileleriyle birleşmesini sağlamış ve evlat edinmeyi kolaylaştırmıştır. Tüm bu değişikliklere rağmen, Birleşik Devletler kan bağına yönelik kültürel önyargısını korumuştur ve hala birçok kişi evlat edinmeyi ikinci sınıf bir aile bağı oluşumu olarak görmektedir. Bu eğilimler, federal yasalar, özel ihtiyaçlar, ırklar arası ve ülkeler arası evlat edinme, evlat edinme süreçlerinde açıklık, evlat edinme kayıtlarının açılması üzerine devam eden ihtilaf ve evlat edinen aileye yönelik damgalama gibi, sona erecek gibi durmamaktadır. Bu faktörler gelecekte de Birleşik Devletlerdeki evlat edinmeyi etkileyen faktörler olarak kalmaya devam edecek gibi durmaktadır.

Amerikan hukukunda da evlat edinme kurumu kabul edilmekle birlikte, Anglo sakson hukukunun özelliklerini taşıdığı için çalışmamızda incelediğimiz ülke hukuklarına göre bazı farklılıklar içermektedir. Bu farklılıklardan biri “Equitable adoption” olarak ifade edilen ve mahkeme içtihatlarına dayanan bir evlat edinme türünün kabul edilmiş olmasıdır. Equitable adoption yönteminde, aralarında evlatlık ilişkisini kuran bir mahkeme kararı bulunmayan anne ve baba ile çocuğun, sanki çocuk kendilerinin çocuğuymuş gibi davranmaları söz konusudur. Bu tür evlat edinmenin esas özelliği, vasiyetname bırakmaksızın ölen evlat edinene, tamamen yabancı olan (akrabalık ilişkisi bulunmayan) bir kişinin tıpkı yasal bir mirasçı gibi mirasçı olmasıdır. Dolayısıyla equitable adoption sadece evlat edinenin ölümünden sonra ileri sürülebilen bir hak sağlar. Amerikan evlat edinme hukukunda open adoption (açı evlat edinme) ile closed adoption (kapalı evlat edinme) ayrımı da bulunmaktadır. Açı evlat edinmede, doğum yapan anne yani doğal anne çocuğunu evlatlık olarak alacak kişiyi ya da aileyi seçme hakkına sahiptir. Kapalı evlat edinmede ise, doğum yapan anne yani biyolojik anne evlat edinme sürecini yönetemez; çocuk üzerindeki tüm hakları kaybeder ve çocukla ilgili tüm süreç artık yetkili kamu kuruluşunun bünyesinde gerçekleştirilmektedir.

97 Altuğ, s. 249.

98 Ancak yukarıda incelediğimiz Vermont eyaleti bu kuralın istisnasını düzenlemiş ve evlatlı̆̆ın öz ana ve babasına da mirasçı olabileceğini kabul etmiştir. 
Amerika'da federal düzeyde geçerli olan bir Uniform Adoption Act bulunmakta; eyaletler ise bu Act çerçevesinde kendi evlat edinme yasalarını uygulamaktadırlar. Dolayısıyla her eyaletin aradığı şartlar birbiriyle aynı olmamaktadır. Amerika’nın Vermont eyaleti, Uniform Adoption Act'i birebir uygulan tek eyalettir.

Vermont eyaletinde evlat edinme, diğer ülke hukuklarının pek çoğunda olduğu gibi küçüklerin evlat edinilmesini esas almıştır. Ancak sadece küçüklerin değil, eyalet kanununda aranan bazı şartların da oluşmasıyla erginlerin yani yetişkin bireylerin de evlat edinilmesi mümkün olmaktadır. Önemli olan kanun tarafından aranan şartların sağlanması ve bu konuda yetkili mahkemenin evlat edinmeye karar vermesidir.

Küçüklerin evlat edinilmesinde, uluslararası bir ilke olan “çocuğun yüksek yararı"nı benimsemiştir. Dolayısıyla bir küçüğün evlat edinilebilmesi, ancak onun yararının bulunduğu durumlarda söz konusu olabilmektedir. Evlat edinme ise bir mahkeme kararı ile gerçekleşmektedir. Evlat edinme kararı verilirken ise, öncelik her ne kadar çocuğun yararı olsa da hâkimin geniş bir takdir hakkı bulunmakta ve hâkim evlat edinmek isteyen kişilerin bir çocuğu bakıp büyütmek, onu eğitmek konusunda yani doğru ebeveynlik yapmak bakımından yeterli olup olmadığını da göz önünde bulundurmaktadır. $\mathrm{Bu}$ husus da hâkime pek çok ülke hukukunda olmayan bir yetki olarak tanınmaktadır.

Evlat edinmeye karar verilmesiyle birlikte, evlat edinilen ile evlat edinen/edinenler arasinda bir soybağ 1 ilişkisi kurulmakta; bunun bir sonucu olarak da öz anne ve babaya ait hak ve yükümlülükler evlat edinen kişi ya da kişilere geçmektedir.

\section{KAYNAKÇA}

A. Güvercin (2005). Yabancıların Evlat Edinmelerinin Uluslararası Hukuk Açısından İncelenmesi ve Türk Hukuku ile Amerikan Hukukunda Evlat Edinmeye İlişkin Düzenlemeler. Yayınlanmamış Yüksek Lisans Tezi, Kocaeli: Kocaeli Üniversitesi, Sosyal Bilimler Enstitüsü

A. J. Matusow (1984). The Unraveling of America: A History of Liberalism in the 1960s. Harper and Row, New York.

A. Kadushin (1980). Child Welfare Services, 3d ed., Macmillan, New York.

B. A. Garner (2009). Black's Law Dictionary.

B. Q. Madison/M. Schapiro (1973). Black Adoption-Issues and Policies: Review of the Literature. Social Service Review 47, s. 531-560.

B. Wishy (1967). The Child and the Republic: The Dawn of Modern American Child Nurture. University of Pennslyvania Press, Philadelphia.

C. R. Mabry/L.Kelly (2006). Adoption Law: Theory, Policy, and Practice, Buffalo. NY

D. R. Rapke (1999). A Critical History Of American Adoption Law. 102 W. Va. L. S.

E. A. Hoyt/M. Sherman (1996). Adoption and the Law in Vermont, 1804-1863: An Introductry Essay. Vermont History 64: 159-173.

E. Gray (2009). Open versus Closed Adoption. The Journal of Undergraduate Nursing Writing. Volume 3, Number 1, s. 27

E. W. Carp (1998). Family Matters: Secrecy and Disclosure in the History of Adoption. Harvard University Press, Cambridge. 
E. W. Carp (2002). Adoption in America: A Historical Overview of American Adoption, University of Michigan Press.

E. T. May (1995). Barren in the Promised Land: Childless Americans and the Pursuit of Happiness. Basic Books, New York.

G-F.D. Ma (1948). One Hundred Years of Public Services for Children in Minnesota. University of Chicago Press, Chicago.

G. K. Behlmer (1998). Friends of the Family: The English Home and its Guardian. Chap. 6, Stanford University Press, Stanford.

G. P. Ahlers (2014). Adoption Law In The United States: A Pathfinder. Child And Family Law Journal, Vol:2:21

H. Altstein/R. J. Simon (1990). introduction to Intercountry Adoption: A Multinational Perspective, New York.

H. Altstein/R. J. Simon (1977). Transracial Adoption:An Examination of an American Phenomenon. Journal of Social Welfare 4, s. 65.

H. D. Krause/L. D. Elrod/M. Garrison/J. T. Oldham (2003). Family Law. Cases, Comments, and Questions. Minnesota.

H. Fradkin (1958). Adoptive Parents for Children with Special Needs. Child Welfare 37, s. 1-6.

H. L. Witmer (1963). Independent Adoptions: A Follow-up Study. Russell Sage Foundation, New York

J. Demos (1970). A Little Commonwealth: Family Life in Plymouth Colony. New York University Press, New York

J. E. Rein (1984). Relatives by Blood, Adoption, and Association: Who Should Get What and Why (The Impact of Adoptions, Adult Adoptions, and Equitable Adoptions on Instate Succession and Class Gifts). 37 Vanderbilt Law Rewiew. s. 711 - 770.

J. H. Hollinger (1995). "Aftermath of Adoption: Legal and Social Consequences,"in Adoption Law and Practice, 1995 supp.,ed.Hollinger et al.(New York: Matthew Bender, 1995), 2:51, app. 13-A.

J.S. Zainaldin (1979). The Emergence of a Modern American Family Law: Child Custody, Adoption, and the Courts, 1796-1851. Northwestern University Law Review 73, s. 1038-1089.

L. Gaddie (2009). Open Adoption. Journal of the American Academy of Matrimonial Lawyers. Vol. 22, s. 501.

L. Kuntz (2013). Das geseztliche Erbrecht des Adoptivkindes in den USA. München: Carl Heymanns Verlag.

M. Grossberg (1985). Governing the Hearth: Law and the Family in Nineteenth-Century America, University of North Carolina Press

McCauliff(1986). The First English Adoption Law and Its American Precursors, Seton Hall Law Rewiew, 16:656-77.

N. R.Cahn (1999).Children's Interest in a Familial Context: Poverty,Foster Care, and Adoption. Ohio State Law Journal 60, s. 1189-1190.

R. P. Barth, “A Decade Later: Outcomes of Permanency Planning,"in The Adoption Assistance and Child Welfare Act of 1980 (Public Law 96-272): The First Ten Years (St. Paul, Minn.: North American Council on Adoptable Children, 1990);

P. Romanofsky (1969). Early History of Adoption Practices, 1870-1930. University of Missouri at Columbia,

R. A. W. Howe (1983). Adoption Practice, Issues, and Laws, 1958-1983. Family Law Quarterly Vol. 17, No. 2, s. 182.

R. C. Bell (1999). Virtual Adoption: The Diffuculty of creating an exception to the Statury Scheme. Stetson Law Reiew. Vol. XXIX.

R. Frank (1956). What the Adoption Worker Should Know about Infertility, Child Welfare 35, s. 1-5.

R. Gordon (1999). Drifting Through Byzantium: The Promise and Failure of the Adoption and Safe Families Act of 1997. Minnesota Law Review 83, s. 637-701 
R. L. Jenkins (1935). On Adopting a Baby: Rules for Prospective Adoptive Parents, Hygeia 13, s. 1068 vd.

R. Muncy (1991). Creating a Female Dominion in American Reform, 1890-1935. chap. 2. Oxford University Press, New York.

R. Pannor/A. Baran (1984). Open Adoption as Standard Practice. Child Welfare 63, s. 245-250.

S. B. Presser,The Historical Background of the American Law of Adoption, Journal of Family Law 11 (197172): 443-516.

W.M.Mcgovern, S.F.Kurtz ve J.E.Rein (1988). Wills, Trusts, and Estates. Including Taxation and Future Interests. St. Paul, Minnesota.

Y. Altuğ (1957). Türk ve Birleşik Amerika Devletleri Hukukunda Evlat Edinme Üzerinde Bir İnceleme. İÜHFD, 22(1-4). İstanbul,

Z. R.Turitz,(1967). Development and Use of National Standards for Child Welfare Services,"Child Welfare 46, s. 246-248. 